\title{
3BIT \\ ПРО НАУКОВО-ДОСЛІДНУ РОБОТУ \\ «МЕДИЧНИЙ ЕЛЕКТРОННИЙ ПАСПОРТ ГРОМАДЯНИНА УКРАЇНИ»
}

\author{
Науково-дослідну роботу (НДР) виконано Національною медичною академією \\ післядипломної освіти імені П. Л. Шупика МОЗ України.
}

\author{
Основні автори розробки: Мінцер О. П., д-р мед. наук, професор (науковий \\ керівник); Петров В. В., член-кор. НАН України; Крючин А. А., член-кор. НАН \\ України; Бабінцева Л. Ю., канд. фарм. наук, доцент (відповідальний \\ виконавець); Горбов І. В., К.т.н., Денисюк М. С.
}

Реферат роботи.

Звіт про НДР: 404 с., 77 рис., 23 табл., 137 джерел, 10 додатків.

Мета науково-дослідної роботи - створення механізмів інформаційного відображення здоров'я людини протягом ії життя, забезпечення моніторингу рівня здоров'я населення, наступності та спадкоємності медичних дій, надання інформаційної підтримки лікарям уприйнятті рішень, підвищення якості медичної допомоги в Україні.

Основні завдання науково-дослідної роботи:

- проведення аналізу щодо уніфікації медичної документації в Україні;

- створення технічного рішення щодо матеріального носія інформації медичного електронного паспорта (МЕП), його структури і функціонального факторіалу;

- обгрунтування механізмів забезпечення валідності інформації;

- розробка медичних і технічних вимог до програмного забезпечення;

- обгрунтування інтеграції МЕП з інформаційними системами різного рівня;

- розробка принципової схеми глобальної системи ведення електронної медичної документації з використанням інформації МЕП.

Об’єкт дослідження - форми медичної документації, нормативно-правова база, методологія електронного документообігу в медичних закладах, схеми матеріальних носіїв інформації, показники здоров’я населення.

Основні результати досліджень:

1. Обгрунтовані принципи формалізації структури уніфікованої історії хвороби, забезпечення валідності інформації, розроблено методологічну базу для створення єдиної уніфікованої медичної документації. Проаналізовані існуючі МІС та сформульовані вимоги щодо їх інтеграції з МЕП.

2. Запропонований принципово новий механізм реєстрації даних про здоров'я людини за допомогою функціонально незалежного носія інформації. Визначені елементи нормативно-правової бази України для запровадження МЕП.

3. Вперше сформульовані концептуальні підходи до створення дуальної державної системи: розгалуженої IC та МЕП. Розроблені принципові схеми обміну інформацією в інформаційному просторі МОЗ України.

4. Розроблений оригінальний матеріальний носій для МЕП на базі мікроконтролера та мікросхеми флешпам'яті. Для контролера розроблено програмне забезпечення, що здійснює багаторівневий доступ до медичних даних.

5. Сформульовані та обгрунтовані основні медико-технічні вимоги до програмного забезпечення МЕП.

6. Впершезапропоновані для занесення у МЕП: оцінки індивідуального здоров'я людини; механізми формування ризиків захворювань, відображення їх динаміки; віддзеркалення фармацевтичного навантаження на організм тощо.

Ключові слова: медичний електронний паспорт, бази даних, портативні носії інформації, цифровий запис інформації, якість медичної допомоги, інформаційно-телекомунікаційна система, комплексна система захисту інформації, оцінка здоров'я населення, мікроконтролер, медико-технічні вимоги.

Вступ. Одним з пріоритетів державної політики у забезпеченні тривалого соціально-економічного розвитку України визначено збереження й зміцнення здоров' я населення на основі формування здорового способу життя та підвищення доступності й якості медичної допомоги.

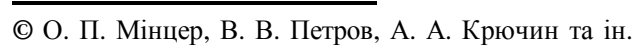


Медична галузь тісно пов' язана з накопиченням і обробленням значних обсягів інформації. Від якості методів роботи з інформацією залежить ефективність надання першої допомоги та в подальшому лікування пацієнта. 3 метою забезпечення належної якості медичної допомоги існує потреба в накопиченні й аналізі даних впродовж тривалого періоду, застосуванні електронних експертних систем.

В свою чергу ефективне функціонування системи охорони здоров'я визначається такими загальними системоутворюючими факторами:

- вдосконалення організаційної структури медичної інформаційної системи, що дозволяє забезпечувати формування здорового способу життя та надання якісної медичної допомоги всім громадянам України (у межах державних гарантій);

- розвиток інфраструктури та ресурсного забезпечення охорони здоров'я, що містять фінансове, матеріально-технічнета технологічне оснащення закладів охорони здоров'я на основі інноваційних підходів і принципу стандартизації;

- наявність достатньої кількості підготовлених медичних фахівців, які спроможні вирішувати завдання, що ставляться перед системою охорони здоров'я України.

Зауважимо, що стан справ в охороні здоров'я значною мірою визначають організація інформаційної служби та наукової медичної інформації зокрема.

Збір та обробка медичної інформації на різних рівнях системи охорони здоров'я на сучасному етапі розвитку ведеться з використанням різноманітних засобів комп'ютерних технологій. Але індивідуальні електронні носії медичної інформації почали застосовуватися в різних країнах світу відносно недавно. Найчастіше там використовують спеціальні смарт-карти, до яких вноситься тільки текстова інформація обмеженого обсягу.

На початку цього сторіччя одним з авторів цього дослідження (проф. О.П. Мінцер, 2001-2005) було запропоновано свій власний варіант вирішення поставленої проблеми, що не має аналогів у світі. Його суть полягає у створенні функціонально незалезнного мобільного медичного електронного паспорта, що дозволяє людині мати при собі необхідну інформацію стосовно ії здоров' я. При цьому в МЕП міститься вся інформація від народження людини до моменту потреби в конкретних даних як пацієнта. Останнє дозволяє забезпечити прийняття кваліфікованого медичного рішення в нестандартних ситуаціях: при мандрівках людини, при втраті свідомості, в місцевості, де немає комунікацій тощо. Сучасний електронний документ, що відображає стан здоров'я, надає найкращим чином можливість забезпечити наступність медичних дій, віддзеркалити динаміку здоров'я та/або патологічного процесу у людини.

Вже на перших етапах розроблення МЕП розглядалась можливість використання у якості матеріального носія малих оптичних дисків [32, 37]. Проте, суттєвою перепоною на тому етапі стала недостатня інформаційна ємність подібних носіїв інформації, а також недосконалість розробленого системного та прикладного програмного забезпечення.

Поява нових інформаційних технологій, зокрема DVD та Blue-ray, дозволяє на окремому носієві (компактдиску) записати вже значно більший обсяг інформації (до 500 Мб). Але й ця місткість не дозволяла вирішувати проблеми мобільного носія інформації про здоров’я індивіда. Окрім того, новітні носії мали високу вартість. Лише в останні декілька років з'явилася можливість використання ефективних та не дорогих носіїв інформації.

Вочевидь, МЕП, у порівнянні зі звичайною (паперовою) медичною карткою, для взаємодії лікар - пацієнт має безліч переваг. Це, по-перше, компактність при великому обсязі інформації; надійність і можливість дублювання інформації, що зберігається. Слід також зазначити доступність інформації (у тому числі і для подальшої обробки), що збережена у вигляді цифрових даних; зручність роботи; забезпечення конфіденційності даних, можливість встановлення кількох рівнів доступу. Суттєве значення має можливість контролю за ходом лікування при виникненні конфліктних ситуацій.

Проголошення нової ідеології охорони здоров'я було позитивно сприйняте ВООЗ, за ініціативи якої була розпочата міжнародна компанія «Здоров'я для всіх». А на 51-й сесії (травень, 1998) країни-члени ВООЗ звернулися до всіх народів і урядів із закликом прийняти і реалізувати концепцію «Здоров' д для всіх у 21-му сторіччі». Цей документ $є$ посібником з політики та стратегії досягнення здоров’я для населення всіх країн.

Можна стверджувати про появу нових реалій у житті людства, існування яких пов'язане з прискоренням темпів соціальних, економічних, технологічних, екологічних, кліматичних і інших змін та призводить до формування нових проблем стосовно стану здоров'я населення [14]. Наш сучасник істотно відрізняється від своїх предків: зниженням функціональних резервів органів, систем, організму в цілому, порушенням реактив- 
ності і резистентності, процесів саморегуляції і репродукції (зниження кількості та погіршення якості статевих клітин), народження ослаблених нащадків тощо.

Стає очевидною необхідність формування нової стратегії охорони здоров'я, здатної відновити втрачену гармонію в діяльності механізмів самоорганізації живої системи й особи, суть якої- «управління» здоров'ям індивіда, зміцнення і гармонізація механізмів самоорганізації живої системи.

Отже, використання МЕП дійсно можепринести реальну користь за рахунок моніторингу показників здоров'я людини.

Ще одним шляхом, пов 'язаним у тому числі з підвищенням якості надання медичної допомоги населенню, є реєстрація кількісних показників результатів наданої допомоги, кількісних змін у стані здоров'я людини. Основні кошти, що виділяються бюджетом на охорону здоров'я, йдуть саме на лікування хворих. Але цей шлях, як виявилося, на думку експертів ВООЗ грає невелике значення, а саме $8-10$ \% в загальному комплексі чинників, що визначають стан здоров'я населення. Наприклад, в Україні встановлена повна відсутність зв'язку між оснащеністю охорони здоров'я фахівцями, апаратурою та лікарськими засобами (ЛЗ), з одного боку, і показниками захворюваності та смертності - $з$ іншого [14].

Більш того, практично неможливо простежити за характеристиками якості надання медичної допомоги. В цьому сенсі прецедент появи концепції МЕП, що містить інформацію як про надану допомогу, ії якість, моніторинг стану здоров'я людини та/або являє собою ключ доступу до відповідного розділу медичної бази даних (спільної у межах країни або навіть у світових межах), не може не обумовити безліч обговорень, що охоплює не лише галузь медицини, але й юриспруденції, економіки, політики та новітніх технологій. I хоча у суспільстві формуються різні погляди на методи впровадження єдиних форм реєстрації інформації про здоров’я людини, своєчасність і необхідність впровадження даного підходу не викликає сумнівів.

Понад 40 років тому в різних країнах розпочалися роботи щодо стандартизації медичної термінології. За цей час найбільших успіхів досягли США і Великобританія. У першій були розроблені Уніфікована мова медичних систем - UMLS, та велика номенклатура медичних термінів - SNOMED, у другій - Клінічні коди Рида - RCC.

Для передавання, аналізу, архівування та збереження медичних цифрових діагностичних зображень та пов'язаної з ними медичної інформації був створений комплекс засобів та методів - PACS (Picture Archiving Communication System). Водночас використання телекомунікаційних та електронних інформаційних (комп'ютерних) технологій для надання планової та невідкладної медичної допомоги на відстані привело до виникнення нової інформаційної галузі - телемедицини.

Встановлення спеціалізованого програмного пакета на персональний комп’ютер перетворює його в автоматизоване робоче місце (АРМ) лікаря.

Існуючі сьогодні системи (електронна історія хвороби) мають два великих недоліки. Перший - проблема надійності зберігання даних і забезпечення таємності, тому що в ній використовуються лінії обчислювальних мереж через Інтернет. Другий - проблема вартості, оскільки установити нову комп'ютерну систему необхідно як у пацієнта, так і в лікарні.

У всьому світі створена достатня кількість медичних інформаційних систем, проте у практичній охороні здоров'я можливості сучасних автоматизованих інформаційних технологій використовуються обмежено. Це пов' язано зі складністю ведення медичних стандартів й уніфікації медичної документації та тим, що зазвичай кожна МІС створюється виходячи зі специфічних особливостей конкретного медичного закладу.

Проте МЕП не може розглядатися як самодостатня інформаційна система, оскільки в межах медичних закладів існують інші локальні медичні інформаційні системи, на рівні держави вже зароджується інформаційна система національного рівня - ГРІД. Стає актуальною задача аналізу взаємодії між МЕП та іншими інформаційними системами різних рівнів.

Впровадження МЕП для України матиме значний вплив не лише у галузі медицини, але й на політичний i економічний стан розвитку. 


\section{МЕДИЧНІ АСПЕКТИ СТВОРЕННЯ МЕП}

Співавтори даного розділу НДР: Корнелюк О.І., член-кор. НАН України, д-р біол. наук, проф., Апанасенко Г.Л., д-р мед. наук, проф., Мохначов С.І., к.мед.н., Іванова Т.П., Горшков С.В.

\section{1. Структура медичної інформації в МЕП.}

Інформація, що вноситься до МЕП, має бути структурованою. Авторами НДР визначена структура, що складається 37 кластерів і 25 розділів медичних даних:

I. Кластер «Медико-генетична інформація».

Містить 3 розділи:

а) догравідарна група показників;

б) генетична інформація;

в) показники навколишнього середовища.

II. Кластер «Інтегральні показники динаміки життєдіяльності індивіда».

Містить 4 розділи:

а) динаміка факторів ризику;

б) динаміка інтегральних факторів ризику;

в) відображення суттєвих змін у здоров'ї людини, що можуть призвести до незворотних змін в організмі;

г) база даних (таблиця) про фармацевтичне навантаження на організм людини.

III. Кластер «Показники індивідуального здоров'я».

Містить 3 розділи:

a) інтегральні показники здоров'я;

б) маніфестаційні показники здоров'я;

в) непрямі показники здоров'я.

IV. Кластер «Негативні показники здоров'я (патологічних станів)».

Містить 11 розділів:

а) анамнестичні дані;

б) скарги пацієнта;

в) інструментальні обстеження;

г) лабораторно-біохімічні обстеження;

д) спеціальні обстеження;

е) хірургічні втручання;

ж) інформація про реабілітацію;

3) епікризна інформація;

и) морфо-гістологічна інформація;

к) судово-медична інформація;

л) висновки консультантів та експертів;

м) динаміка патологічних станів.

V. Кластер «Інформація для надання невідкладної допомоги індивіду».

Містить 1 розділ:

а) група крові, основний діагноз, певні ризики тощо.

VI. Кластер «Статистична та соиіальна інформачія».

Містить 2 розділи:

а) дані, яких потребує державна звітність (офіційна статистика);

б) інформація, що необхідна для функціонування страхової медицини.

VII. Кластер «Довідкова інформачія».

Містить 1 розділ:

а) дані щодо ідентифікації індивідуального медичного паспорта, ідентифікації особи, належності людини до певних реєстрів населення (Чорнобильського, за групою діагнозів тощо).

Розглянемо найважливіші з представлених кластерів і розділів.

2. Можливості генетичної паспортизації як методу популяційного скринінгу для діагностики захворювань та фармакогеномного аналізу. 
Серед важливих розділів інформації МЕП особливе місце займають генетичні відомості або так званий генетичний паспорт. Коротко зупинимося на його змісті.

Сьогодні, завдяки можливості спрямованого впливу на біохімічні процеси в генах, у лікарів з'явився ефективний інструмент для лікування пацієнтів, продовження життя та підвищення його якості. Перехід від краси та молодості до старості обумовлений генетично. Але, за допомогою розроблених на основі генетичної паспортизації рекомендацій з добору індивідуальної дієти та фармакотерапії, режиму руху та естетичних процедур, а також за рахунок поліпшення навколишнього середовища, оцінки істинної значимості шкідливих звичок і відмови від них, стає можливим управляти цим процесом.

Знання генетичних основ патологічного процесу забезпечує можливість визначення генетичної особливості захворювання окремого пацієнта (генодіагностика), завдяки чому можна скласти рекомендації для проведення повноцінного комплексу профілактичних заходів. Впровадження в медицину такого підходу дасть змогу розширити арсенал методів терапії, а можливо і гемотерапії. Іншими словами, з'являється науково обгрунтований метод, завдяки якому з певною мірою ймовірності можна оцінити ризик розвитку тих чи інших захворювань будь-якої людини, та, якщо виконувати спеціально розроблені профілактичні заходи, - відкласти їх прояви.

Використання діагностичних методів, заснованих на аналізі генетичних маркерів, дозволяє здійснювати ранню діагностику захворювання у пацієнтів без виражених клінічних проявів патології та своєчасно призначати адекватну терапію. Адекватність лікарської терапії залежить від індивідуальних генетичних особливостей пацієнта. Завдяки генодіагностиці у декілька разів скорочується час добору препаратів та визначення їх дозування, з'являється можливість призначити більш ефективні схеми лікування, а також знизити кількість ускладнень, пов'язаних з несприятливими лікарськими реакціями.

Спадковість, у правильному розумінні, - не гральні кубики долі. Вона, скоріш, - безліч потенцій. Яка частина $з$ безлічі потенцій буде реалізована, визначається чинниками середовища, біографією індивіда. Тільки фанатичні прихильники міфу про генетичне визначення можуть сумніватися в тому, що життя кожної людини пропонує безліч варіантів, з яких тільки частина, ймовірно - нікчемна частина, реалізується фактично. Проблема в тому, до якого ступеня набори варіантів схожі або різні у всіх людей.

\section{Генетичний паспорт}

Генетична паспортизація — новий напрямок в медицині. Хоча визначити всі гени схильності для кожної людини поки неможливо, зараз вже технічно доступний індивідуальний аналіз по декількох десятках генів. Іншими словами, охочі знати свої генетичні характеристики можуть отримати генетичний паспорт. У нім повинна бути інформація про наявність мутацій в генах спадкових хвороб і в генах схильності до мультифакторних захворювань.

Величезний обсяг інформації, записаний в геномній ДНК людини, а також сучасні технологічні рішення дозволили сформувати нові наукові напрямки, зокрема, генотипування з можливістю створення на його основі індивідуального генетичного паспорта людини. Сьогодні повне секвенування геному досить дороге та займає багато часу. Однак для того щоб дізнатись, до яких хвороб є схильність у людини, не $є$ необхідним секвенувати увесь ії геном, достатньо „прочитати” тільки окремі його ділянки: „слова” або навіть „букви”.

Генетичний паспорт людини - це сукупність даних про наявність у геномі індивіда певних точкових змін (мутацій, поліморфізмів), або „сніпів” (від англ. SNP - single nucleotide polymorphism). SNP- однонуклеотидні позиції в ДНК, для котрих у деяких популяціях існують різні варіанти послідовностей (алелі), причому рідкісний алель зустрічається з частотою менш ніж 1\%. На сьогодні виявлено більше 4 мільйонів таких імовірних точок. Це означає, що на кожен ген людини припадає декілька можливих поліморфізмів. Тому, якщо виявити тільки ці місця та не вдаватися до повного аналізу послідовності всього геному, можна зробити висновок про статус генетичного апарату індивіда. Точковий нуклеотидний поліморфізм, а також більш крупні генетичні пошкодження (делеції, хромосомні аберації) спричиняють розвиток як моногенних, так і мультифакторних захворювань.

Генетична паспортизація, або генотипування, має величезне значення для медицини. Комплекс заходів, в тому числі побудова індивідуальних генетичних карт, збирання і аналіз всієї сукупності даних щодо поліморфізму в популяції, визначення медичної значимості мутацій i, нарешті, картування захворювань по групах $\epsilon$ однією із найактуальніших задач не тільки генетики людини, алей практичної медицини.

Можливості генетичної паспортизації як методу популящійного скринінгу для діагностики захворювань та фармакргеномний аналіз. 
Знання генетичних основ патологічного процесу забезпечує можливість визначення генетичної особливості захворювання окремого пацієнта (генодіагностика), завдяки чому можна скласти рекомендації для проведення повноцінного комплексу профілактичних заходів. Впровадження в медицину такого підходу дасть змогу розширити арсенал методів терапії, а можливо і гемотерапії. Іншими словами, з'являється науково обгрунтований метод, завдяки якому з певною мірою імовірності можна оцінити ризик розвитку тих чи інших захворювань будь-якої людини, та якщо виконувати спеціально розроблені профілактичні заходи, - відкласти їх прояви. Використання діагностичних методів, заснованих на аналізі генетичних маркерів, дозволяє здійснювати ранню діагностику захворювання у пацієнтів без виражених клінічних проявів патології та своєчасно призначити адекватну терапію. Адекватність лікарської терапії залежить від індивідуальних генетичних особливостей пацієнта. Завдяки генодіагностиці у декілька разів скорочується час добору препаратів та визначення їх дозування, з'являється можливість призначати більш ефективні схеми лікування, а також знизити кількість ускладнень, пов'язаних з несприятливими лікарськими реакціями.

Попередження остеопорозу в постменопаузі

Можливості проведення генетичної паспортизації грають важливу роль для профілактики вікових патологічних процесів. Виявлено кореляцію між частотою переломів і алелями гена рецептора вітаміну D (VDR) зокрема, поліморфізму BsmI. Дослідження показали, що наявність поліморфізму BsmI в гетерозиготному стані збільшує загальний ризик переломів у 1,5 раза, в гомозиготному стані - більш ніж у 2 рази. Гомозиготний поліморфізм T/T у гені колагену COLIA1 Sp1 (G/T) спричиняє у жінок значне зменшення щільності кісткової тканини шийки стегнової кістки і хребта, та у 1,4 раза збільшує ризик перелому хребта, а поліморфізм гена фарнесилдифосфатсинтази (FDPS) у жінок похилого віку на 3-7 \% зменшує кісткову масу. Наявність поліморфізму Cdx2, промотора гена VDR, на $20 \%$ знижує ризик переломів хребта незалежно від статі людини. Гомозиготний поліморфізм Xbal у гені $\alpha$-рецептора естрогену (ESR1) зменшує загальний ризик переломів у жінок будь-якого віку на 19\% (у чоловіків - на $9 \%$ ) і ризик переломів хребта - на 35\% (у чоловіків - на 16\%). Несприймання лактози (молочного цукру) через генетичний варіант С/С поліморфізму -13910 Т/С гена лактази LCT та неусвідомлене прагнення відмовитися від молочних продуктів (клінічна картина схожа на хронічний панкреатит), призводить до значного зменшення кісткової маси та 2-5-кратного збільшення ризику переломів у людей похилого віку. Цей поліморфізм зустрічається у 1-7\% популяції у Швеції, 10-18\% - у Німеччині, 20-25\% - у Австрії, 20-40\% - у Швейцарії, 50-60\% - у Греції, Іспанії та Італії, більш 75\% - у Туреччині; тобто чим південніше ареал проживання популяції, тим частіше зустрічається варіант С/С. Цим пояснюється відсутність в кухні південних народів страв із свіжого молока. У разі виявлення у пацієнта вищезазначених поліморфізмів йому слід приділяти більше уваги дієті, балансу вітаміну D та кальцію, оздоровчим програмам із застосуванням раціональних режимів природної та апаратної інсоляції.

Заняття спортом та фітнесом

Здатність до силових навантажень і швидкісних видів спорту також генетично детермінована. $€$ чимало даних про негативні наслідки інтенсивних тренувань і навіть смерть атлетів. В теперішній час для науково обгрунтованого добору спортсменів активно вивчають особливості роботи генів, які беруть участь у руховій функції. Серед кандидатів на роль генетичних маркерів розглядають і гени, які визначають функції серцевосудинної системи: ген ангіотензиногену (AGT), ген ангіотензинконвертувального ферменту (ACE), ген рецептора I типу ангіотензину II (AGTR1), ген $\beta 2$-рецептора брадикініну ( $\beta 2 B K R)$, ген NO-синтази (NOS). He тільки у професіональній спортивній медицині, а і в елітних фітнес-клубах США та Японії здійснюють генетичне тестування для ухвалення правильного рішення про тренування та фізичні навантаження.

Атеросклероз та тромбоемболічні захворювання

Відомо, що атеросклероз - це гіпертрофований процес „природного” відновлення стінки судин. Перші ознаки атеросклерозу судин можна спостерігати навіть у новонароджених. 3 віком цей процес прогресує, але у різних людей з різною інтенсивністю. Це пов'язано з генетичними факторами, які визначають індивідуальний ліпідний та вуглеводний обмін речовин. Паління, нераціональне харчування, стрес, інфекції сприяють більш швидкому розвитку атеросклерозу. Пізні стадії атеросклерозу судин мозку призводять до інсульту і старечого слабоумства. Для цього $є$ багато причин, але найвагоміша - генетична схильність. Ускладнення атеросклерозу і атеросклеротичного ураження судин спричинюють тромбоемболії судин. Тромбоемболічні захворювання можуть бути викликані порушенням процесів системи згортання крові. В терапевтичних стаціонаpax, де переважно лікуються хворі з серцево-судиними захворюванями, тромбоемболії (ТЕ) легеневої артерії 
зустрічаються у 15-30\% випадків. ТЕ у багатьох випадках є безпосередньою причиною смерті, особливо у післяопераційних хворих та хворих на рак. Встановлено, що серед хворих на рак при наявності ТЕ смертність збільшується у декілька разів, при цьому наявність емболії значно перевищує средньостатистичні показники. Причини більшості ТЕ у хворих на рак та у хворих після значних хірургічних втручань слід шукати у лікарській терапії, не узгодженій з генетичною схильністю хворого. Частота тромбозів артерій серця при інфаркті міокарда становить 70-85\%. Тромбози судин мозку обумовлюють розвиток інсультів у 75-80\% випадків. В останні роки у зв'язку з відкриттям раніше невідомих генетично обумовлених дефектів системи згортання крові, які сприяють тромбозу (поліморфізм фактора V (Ляйден), протромбіну та ін.), стало можливим пояснення випадків тромботичних ускладнень. Особливістю поліморфних варіантів даних генів $є$ те, що вони можуть тривалий час ніяким чином себе не виявляти. Патологічні симптоми можуть проявитися при додаткових умовах, таких як особливості харчування, вагітність, прийом деяких ліків, спосіб життя та інші. У зв'язку з цим основною проблемою даної області сучасної медицини стає виявлення генетичних маркерів тромбофілії та обробка за допомогою фармакогноміки режимів протитромботичної терапії (дозування антикоагулянтів і тривалості їх призначення).

Метаболізм фолієвої кислоти та пов'язані з ним захворювання.

Роль генетичної паспортизації у сучасній медичній діагностиці яскраво ілюструють дані щодо поліморфізмів метилентетрагідрофолатредуктази (MTHFR) - ферменту, який відіграє ключову роль у метаболізмі фолієвої кислоти. MTHFR каталізує відновлення 5,10 - метилентетрагідрофолату у 5-метилтетрагідрофолат. Останній становить активну форму фолієвої кислоти, необхідної для синтезу метіоніну із гомоцистеїну і далі - утворення S-аденозилметіоніну - головного учасника метилування ДНК. Дефіцит MTHFR має не тільки тератогенний (такий, що пошкоджує плід), а й мутагенний (такий, що пошкоджує ДНК) вплив. У теперішній час відомо біля двох десятків мутацій цього гена, які порушують функцію ферменту. Найбільш вивченою мутацієює варіант, у котрому нуклеотид цитозин (С) в позиції 677 замінений тимідином (Т). Наявність гомозиготи 677Т/Т виявленоу 10-16\% європейців. Поліморфізм 677T гена MTHFR пов' язаний з чотирма групами багатофакторних захворювань: серцево-судинними хворобами, дефектами розвитку плода, колоректальною аденомою та раком молочної залози та яєчників. Гіпергомоцистеїнемія (ГГ). Амінокислота гомоцистеїн є проміжним продуктом процесу синтезу метіоніну. Однією з причин надлишкового накопичення гомоцистеїну в плазмі крові- гіпергомоцистеїнемії - $€$ порушення роботи ферменту MTHFR. Наявність гомозиготної форми 677T/T приводить до майже 10-кратного підвищення ризику ГГ. У пацієнтів з ГГ було відмічено позитивний рівень фолієвої кислоти та вітаміну В12, вони споживали більше кави та палили частіше, ніж здорові донори. Корекцію ГГ можна проводити додатковим введенням в раціон кофакторів, необхідних для метаболізму гомоцистеїну-фолієвої кислоти, вітамінів B12, B1 i B6. У носіїв T/Т-генотипу MTHFR при оптимальному споживанні фолатів рівень гомоцистеїну пидвищений помірно. Максимальний захист для таких людей - перехід на все життя на фолієву зеленолистову дієту, яка передбачає підвищенне (не менш 500 г на добу) споживання свіжої зелені та темно-зелених яблук, зеленої капусти, шпинату, селери, а також вишні, авокадо та свіжих сирів. Необхідно виключити споживання розчинної кави, котра містить синтетичні домішки, які уповільнюють зниження рівня гомоцистеїну, і кисломолочного сиру, який містить надмірну кількість метіоніну.

Дефекти розвитку плода. Підвищення частоти виявлення алеля 677Т було відмічено не тільки при пізньому токсикозі (гестозі), але і при інших ускладненнях вагітності (відшарування плаценти, затримка розвитку плода, дефект нервової трубки, пренатальна смерть плода). Поєднання мутації 677Т з іншими факторами ризику призводить допідвищення вірогідності раннього викидня.

Сериево-судинні захворювання. При дослідженні зв'язку між мутацією 677Т та серцево-судинними захворюваннями виявлено, що гомозиготна мутація 677Т/Т зустрічається набагато частіше в групі пацієнтів, ніж у здорових донорів. У молодих пацієнтів з ішемією артерій гомозигота Т/Т зустрічається у 1,2 раза частіше. Невисокий ступінь ризику пов' язаний з гетерогенністю аналізованих вибірок населення. При дослідженні гомогенних вибірок населення (індивідуальні дослідження, а не мета-аналіз) оцінки ступеня ризику значно вищі. Так, різниця частоти виявлення гомозигот Т/Т у пацієнтів та у здорових донорів відповідала 3кратному підвищенню ризику кардіоваскулярних захворювань у молодому віці.

Розвиток передракових і ракових станів колоректальної ділянки. Виявлений певний взаємозв'язок між поліморфізмами MTHFR і розвитком передракових і ракових станів колоректальної ділянки. Проведено дослідження значної групи хворих з поліпозом товстого кишечника. Визначали рівні фолату у еритроцитах $\mathrm{i}$ 
наявність поліморфізму C677T гена MTHFR. Отримані результати виявили зв'язок між зниженим вмістом фолату і ризиком розвику аденоматозу. Багатофакторний аналіз показав, що паління, фолатний статус і генотип MTHFR $\epsilon$ істотними компонентами високого ризику аденоматозу. Цей ризик виявився вельми великим у осіб з низьким рівнем фолату, які виявились носіями алеля 677Т в гомо-або гетерозиготній формі. Отримані дані вказують на взаємний вплив харчування і генних факторів при розвитку передракових станів.

Ризик розвитку патології при хіміотерапї раку. Поліморфізм 677Т впливає на ефективність хіміотерапії раку. Практично всі препарати цитостатичної дії, які застосовуються в протипухлинній терапії, тератогенні, зокрема метотрексат - антиметаболіт, дія котрого зв'язана з інгібуванням активності ферменту MTHFR. Дослідження невеликих вибірок хворих на рак грудей показало, що при наявності гомозиготи T/Т ризик розвитку побічних ефектів при застосуванні метотрексату збільшується у десятки разів. Слід зазначити, що і без цієї мутації у жінки, яка отримувала метотрексат до вагітності, підвищенний ризик народження дитини 3 хромосомною патологією. Після лікування цитостатиками, особливо при наявності несприятливого генетичного фону, в обов'язковому порядку рекомендуєтся проведення ультразвукового сканування на різних термінах вагітності для виключення у плода анатомічних вад.

Онкогінекологічні захворювання. Є нечисленні дослідження генотипу MTHFR при онкогінекологічних захворюваннях. Вивчається поліморфізм С677T гена MTHFR у великій групі єврейських жінок, хворих на рак молочної залози і яєчників, включаючи і спадкові форми, пов'язані з мутаціями генів BRCA («гени раку молочної залози»). При такому несприятливому генетичному фоні наявність у хворих Т/Т генотипу виявилося істотним чинником обтяження захворювання. Частота Т/Т генотипу була у 2 рази вища (33 \% проти $17 \%$, $\mathrm{P}=0,0026$ ) серед жінок $з$ двостороннім раком молочної залози і раком яєчника, в порівнянні $з$ основною групою хворих. Жінки з гетерозиготним генотипом C/Т мали подвійний онкологічний ризик, а у хворих з гомозиготним генотипом Т/Т ризик був підвищений втричі, в порівнянні з контрольною групою.

Крім того, знижене споживання фолатів у дієті підвищувало генетичний ризик до п’ятикратного значення, в порівнянні з контролем.

Взаємодія поліморфізмів генів ферментів та інших біологічно активних речовин з курінням призводить до збільшення ризику розвитку різних захворювань.

Тютюнозалежність стимулює розвиток багатьох захворювань, особливо при наявності несприятливих поліморфізмів.

Ангіотензин-конвертуючий фермент (ACE) грає важливу роль в регуляції кров'яного тиску і підтримці балансу електролітів, також впливає на фібриноліз, активацію і агрегацію тромбоцитів. Активність ферменту у крові пов'язана з наявністю варіанту D - делеції, тобто відсутність Alu-послідовності у середині інтрона гена ACE. Наявність варіанту D $€$ чинником ризику розвитку серцево-судинних патологій. Дослідження показали, що при наявності D/D-генотипу паління підвищує ризик развитку захворювання у 2 рази. Генотип D/D $€$ також фактором ризику гострого інфаркту міокарда у пацієнтів молодше 50 років.

Синтаза окиду азоту (NOS) - фермент синтезу окису азоту, який бере участь у вазодилатації (розслабленні васкулярної мускулатури). Окис азоту впливає також на ангіогенез і згортання крові. При дослідженні молодих пацієнтів (20-28 років) було виявлено, що паління значно знижує артеріальну вазодилатацію у хворих 3 поліморфізмом 298D (E298D G-> T).

Протромбін (коагуляиійний фактор II, або F2) - один із головних компонентів системи згортання крові. В ході ферментативного розщеплення протромбіну утворюється тромбін. Ця реакція $є$ першою стадією утворення кров' яних згустків. Мутація гена протромбіну G20210A характеризується заміною нуклеотиду гуаніну (G) нуклеотидом аденіном (А) у позиції 20210. Внаслідок збільшення експресії мутантного гена рівень протромбіну може бути у 1,5-2 рази вище, ніж у нормі. При виникненні тромбозів мутація 20210А часто зустрічається у поєднанні з мутацією Ляйден. Мугація успадковується за автосомно-домінантним типом. Цеозначає, що тромбофілія виникає навіть у гетерозиготного (G/A) носія зміненого гена. Генетичний аналіз групи пацієнток 3 першим інфарктом міокарда віком від 18 до 44 років показав, що варіант 20210А зустрічається в них у чотири рази частіше, ніж у групи здорових людей, що відповідає збільшенню ризику інфаркту в 4 рази. Вірогідність інфаркту особливо висока при наявності інших чинників ризику серцевно-судиннх захворювань. Наприклад, куріння при наявності генотипу 20210А підвищує ризик інфаркту міокарда більш ніж у 40 разів.

м1-глутатіон S-трансфераза (ген GSTM1) бере участь у метаболізмі електрофільних органічних речовин. Делеція гена GSTM1 (GSTM1 null) призводить до повної втрати функції ферменту. Куріння при наявності 
зазначеної мутації призводить до 2,4-кратного підвищення ризику розвитку раку сечового міхура. Окрім того, аналіз генотипів пацієнтів з ішемічною хворобою серця (діагноз підтверджено ангіографією артерій) і групи здорових донорів показав, що курці з делецією GSTM1 захворюють на IXC у 2,2 раза частіше, ніж некурці. Варіант G поліморфізму I105V (A>G) і варіант T поліморфізму A114V (C->T) р1-глутатіон S-трансферази (ген GSTP1) пов'язані з підвищеним ризиком розвитку різних форм раку.

ө1-глутатіон S-трансфераза (ген GSTT1) бере участь в детоксикації хлорметанів та інших промислових канцерогенів. Делеція гена, мабуть, є захисним чинником у некуpwsd. Дослідження пацієнтів з раком легень показало, що у некурців наявність делеції гена GSTT1 призводить до п'ятикратного зниження ризику розвитку захворювання. У пацієнтів, що палять, делеція призводить до двократного підвищення ризику раку легень. У випадках інтенсивного куріння (більше 23 пачок на рік), у пацієнтів з делецією гена GSTT1 ризик розвитку онкологічних захворювань підвищується у 9,3 раза. Дослідження також показали, що куріння при наявності делеції гена GSTT1 призводить до п'ятикратного підвищення ризику захворювання у жінок та до триразового - у чоловіків.

На жаль, виникають труднощі не тільки медичного, але і соціального плану. Виникає багато моральноетичних і юридичних питань. Коли, в якому віці слід проводити генетичне тестування? Хто може мати доступ до його результатів? Можуть чи повинні знати про результати тестування близькі родичі? Як і де зберігатимуться результати? Зокрема, згідно з рекомендаціями комісії Європейського товариства по генетиці людини $(2000,2003)$, генетичне тестування повинно бути суто добровільним, проводитися тільки за наявності інформованої згоди і бути строго конфіденційним. До результатів тестування з відома пацієнта може мати доступ тільки сімейний лікар або фахівець з інтерпретації отриманих результатів. Вони ніяк не можуть і не повинні стати надбанням страхових компаній або працедавців.

Разом з тим, враховуючи зростаючий інтерес до індивідуальної генетичної схильності і, по сугі, невідворотність масового тестування, багато учених висловлюють цілком обгрунтовані побоювання про непідготовленість суспільства в цілому, його правових і юридичних служб до вирішення виникаючих проблем. Виникає стурбованість тим, що з настанням ери персоніфікованої медицини і превентивного лікування, коли дитина вже при народженні отримуватиме генетичний паспорт, цілком реальним може стати i “генетичний апартеїд”, тобто дискримінація людини за їі генетичними ознаками. Щоб запобігти цій генетичній нерівності, законодавство повинно йти в ногу з передовими технологіями. Тільки в цьому випадку можна створити суспільство, де всі будуть рівні в правах, незалежно від стану геному, де будуть усунені всі можливості генетичної дискримінації.

У деяких країнах генетичне тестування проводять за медичними показаннями або просто як платну послугу. Відомості, записані в генетичному паспорті, $є$ лікарською таємницею.

Якщо генетичний паспорт необхідний для здорової молодої людини, охочої знати, що за хвороби можуть чекати її в майбутньому і як запобігти їх розвитку, перш за все потрібно скласти їі родовід і подивитися, на що хворіли родичі. Носійство мутацій, пов'язаних з моногенними хворобами (фенілкетонурією, муковісцидозом), можна визначати, якщо в сім'ї є подібні хворі або ж захворювання зустрічається з високою частотою в тій етногеографічній групі або у тому географічному регіоні, де живе обстежуваний. Якщо серед родичів обстежуваного є більше однієї людини з однаковою мультифакторною патологією, необхідно аналізувати гени схильності до ії розвитку. За наявності чинників ризику, пов'язаних з професією або з особливими умовами середовища, потрібно тестувати гени, що мають відношення до хвороб, які провокуються саме цими чинниками.

Генетичний паспорт може бути максимально корисний, якщо результати тестування аналізуватимуться висококваліфікованим фахівцем з медичної генетики разом з сімейним лікарем.

Проте для введення в життя генетичної паспортизації необхідні не тільки технології геномів і попит на подібні послуги. Потрібні кваліфіковані фахівці-генетики, лікарі, здатні правильно інтерпретувати результати генетичного аналізу. Крім того, суспільство повинне вирішити безліч соціальних і правових питань, що стосуються застосування результатів генетичного тестування, їх конфіденційності.

Можна сподіватися, що медицина поточного століття буде заснована на знанні індивідуальних особливостей геному кожної людини. Це дозволить у багатьох випадках підібрати методи лікування і профілактики захворювань, пов'язаних з умовами середовища.

В результаті проведених досліджень до генетичного паспорта, як розділу МЕП, запропоновано включити таку інформацію: 
- родовід;

· національність;

• каріотип;

• муковісцидоз, фенілкетонурія, гемофілія А, міодистрофія Дюшена, адреногенітальний синдром та інші моногенні хвороби, найбільш розповсюджені в даній популяції;

• дані про досимптомну діагностику генних хвороб з пізньою маніфестацією;

• хвороба Альцгеймера, хорея Гентингтона, нейродегенеративні захворювання, рак товстої кишки, щитоподібної залози тощо;

- дані про скринінг генів схильності;

• онкогенні, гени-провокатори мультифакторних захворювань, цукрового діабету, гіпертонії, ішемічної хвороби серця, атеросклерозу, інфаркту міокарда, аденоми та раку простати, раку легень, наркоманіі, бронхіальної астми, чутливість до СНІДу тощо;

- діагноз;

• рекомендації лікаря-генетика.

Аналіз даних генетичного паспорта надасть змогу оцінити стан здоров' я людини, фактори ризику при плануванні сім’ї, враховувати індивідуальні особливості медикаментозної терапії.

3. Визначення підходів до раннього виявлення відхилень в динаміці показників стану організму від регіональних та популяційних моделей при довготривалому моніторингу.

Виділяють чотири основні типи перебігу хронічних захворювань: стабільний, нестабільний, прогресуючий та хвилеподібний (рис. 1). Кожний тип має свої популяційні та регіональні відмінності.

Встановлено, що за стабільного типу перебігу сума балів для кожного загострення під час диспансерного огляду за весь період спостереження була вища за початкову не більш, ніж на 15 балів. Хворих 3 нестабільним перебігом поділяють на дві групи. Для першої групи характерним є те, що при загостреннях захворювання сума балів збільшується більше, ніж на 15 балів, з наступним поверненням до вихідного значення. До другої групи ввійшли хворі, в яких “гострі” ускладнення виникли на фоні сприятливого перебігу захворювання.

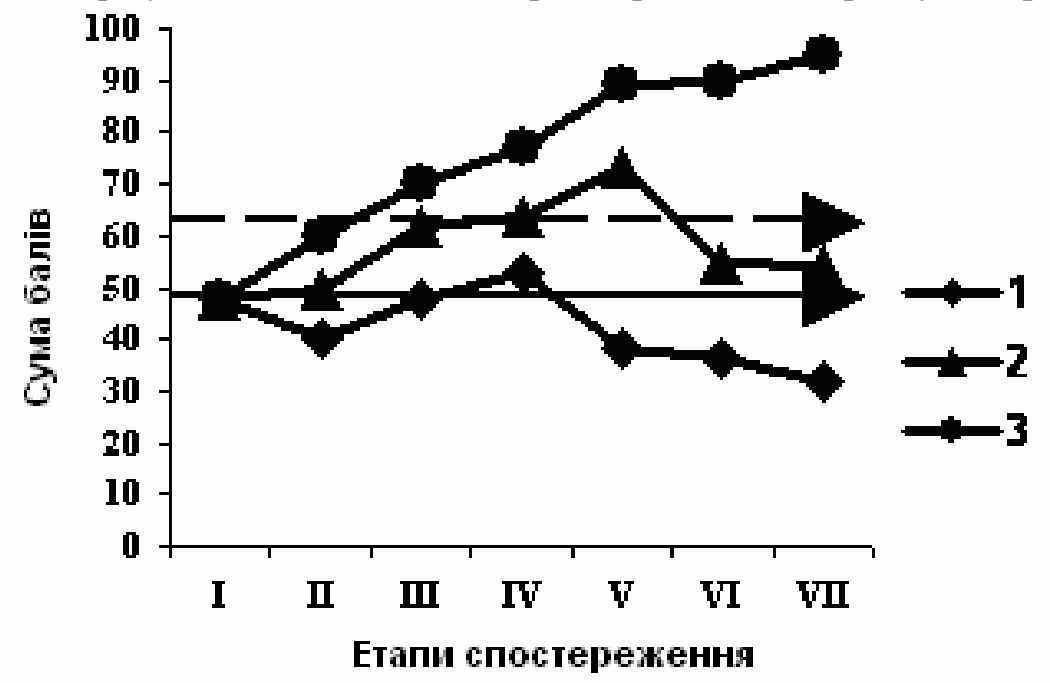

Puc. 1. Основні типи перебігу хронічних захворювань.

1 - стабільний тип; 2 - нестабільний тип; 3 - прогресуючий тип; 4 - хвилеподібний тип.

Прогресуючому перебігу притаманні збільшення суми балів більш, ніж на 15 балів, з наступною стабільністю на новому рівні чи помірне збільшення суми балів при подальшому спостереженні.

Раціональну тактику ведення хворих з хронічними захворюваннями можна подати наступним чином. Якщо в процесі спостереження за пацієнтом кількісне оцінювання його стану не перевищує початкове більш ніж на 15 балів, вважають, що консервативна терапія адекватна, показань до зміни тактики лікування немає. Збільшення суми балів більш, ніж на 15 балів при нестабільному перебігу захворювання вимагає інтенсифікації медикаментозного лікування та обов'язкової консультації відповідного лікаря для встановлення показань щодо оперативного лікування чи мотивованої відмови від нього. Виявлення прогресуючого перебігу є важливим елементом обгрунтування показань до зміни тактики ведення хворих. 
Отже, в процесі моніторингу стану пацієнтів з факторами ризику різних захворювань можна виділити чотири типи перебігу хвороби: стабільний, нестабільний, прогресуючий та хвилеподібний. При стабільному перебігу рекомендується консервативна терапія, при нестабільному - інтенсифікація медикаментозної терапії, нарешті, при прогресуючому потрібна зміна методів лікування.

Звернемо увагу на необхідність впровадження уніфікованих форм реєстрації стану хворого (наприклад, короткого і наочного етапного епікризу). Вони дають змогу не тільки об’ єктивно оцінити динаміку перебігу захворювання та визначити найраціональнішу тактику реабілітаційних заходів, а й значно полегшують ведення документації, звільняють лікаря від традиційних громіздких описів історій хвороби. За умови існування МЕП, наявність таких інформаційних адаптерів дає змогу постійно контролювати стан здоров'я пацієнтів 3 факторами ризику.

Зрозуміло, впровадження МЕП дозволить уточнити частоту факторів ризику різних захворювань, пов' язаних із зовнішнім середовищем, генетичними відхиленнями, особливостями способу життя. Використання сучасних підходів при аналізі інформації (показників відносного ризику і інформативності) надасть можливості більш об' єктивної оцінки впливу факторів ризику на виникнення захворювань і визначити пріоритетні напрямки в профілактиці патології.

Для своєчасного виявлення груп ризику пропонується наступний варіант.

На першому етапі, що проводиться лікарем, виконується розподіл на групи обліку. На основі даних опитування й огляду лікар виділяє 4 групи обліку: I - здорові, які не мають явної патології, з мінімальним ризиком виникнення конкретного захворювання, II - група ризику, це практично здорові, але мають ризики виникнення конкретного захворювання, III - група пацієнтів $33-4$ ступенем ризику виникнення конкретного захворювання; IV група - з наявністю проявів захворювання.

При першому рівні здоров'я, не зважаючи на наявність окремих факторів ризику, організм у цілому адаптований до існування в навколишньому середовищі, не має видимої патології. Це значить, що комплекс факторів навколишнього середовища поки відповідає вимогам гомеостазу організму.

Для підтримки такого рівня здоров'я необхідно виконувати загальногігієнічні вимоги і нівелювати дію наявних факторів ризику додатковими гігієнічними заходами: при надлишковій вазі - відповідна дієта, при контакті із професійними шкідливостями - строге виконання режиму праці, при наявності в минулому захворювань відповідні реабілітаційні заходи. Рівень здоров'я II групи характеризується відсутністю конкретного захворювання, організм пацієнтів адаптований до умов навколишнього середовища, однак наявність певного числа факторів ризику обумовлює нову якість здоров'я (знижені індивідуальні можливості) на відміну від попередньої групи. Крім того, можлива наявність супутніх захворювань створює більш високу можливість виникнення у них конкретного патологічного процесу. Тому в останні роки широко обговорюється питання про доцільну періодичність проведення профілактичних обстежень. Вважаємо за доцільне більш часто проводити обстеження подібних пацієнтів. Вважаємо, що періодичність спостереження для осіб, що не ввійшли в групу ризику, повинна бути 1 раз на рік, для осіб II групи - не рідше 1 разу на шість місяців. Підставою до цього можуть слугувати результати проведеного епідеміологічного дослідження. Спостереження за хворими третьої групи вважаємо необхідним проводити за принципами систем управління ризиками.

Зауважимо, що формування епікризу, що віддзеркалює стан здоров'я в МЕП, здійснюється автоматично в відповідності з заздалегідь сформованими картами ризику. Ця відмінність медичного електронного паспорта і надає унікальні можливості для практичної охорони здоров' я. Дійсно, для лікаря достатньо складно вилучити всі показники з різних методів обстеження, тим більш отриманих в різних лікувальних закладах, що теоретично можуть свідчити ризик виникнення різних захворювань.

Системне обгрунтування стану здоров' я пацієнта та зіставлення існуючих факторів ризику з популяційними та регіональними моделями в динаміці - за суттю, найважливіший принцип ефективності технології МЕП. Саме він дозволить відчути велику практичну користь від застосування МЕП.

\section{4. Обгрунтування системи "Внутрішнього моніторингу" станів паціснтів в МЕП.}

В якості головного механізму оптимізації тактики ведення пацієнтів багатьма вченими розглядається оцінювання ризику.

Клінічний моніторинг як система спостереження, аналізу, оцінки й прогнозування стану здоров'я хворих, $\epsilon$, з одного боку, засобом управління ризиками, а з іншого - системою, що надає відомості про реальний вплив факторів ризику. 
Концепція оцінки ризику практично всіма вченими розглядається в якості головного механізму оптимізації тактики ведення пацієнтів.

На сьогоднішній день системи оцінки ризику (наприклад, шкала SCORE для пацієнтів з ішемічною хворобою серця, що рекомендована для застосування у країнах Європи), не дозволяє оцінювати зміну ризику при корекції деяких модифікованих факторів, таких як рівень загального холестерину, артеріального тиску, куріння тощо. На практиці не використовуються диференційні схеми зміни тактики лікування та профілактичних заходів в залежності від динаміки патологічного процесу, зміни як окремих факторів, так і сумарної оцінки важкості стану пацієнта.

Слід зауважити, що всебічна оцінка ризику впливу на здоров'я всіх потенційних факторів хоча й бажана, але реально нездійсненна, особливо на етапі первинної медико-санітарної допомоги. У зв' язку із цим аналіз зазвичай проводиться на основі детального дослідження обмеженого числа пріоритетних показників.

Методологію оцінки і управління ризиками можна розглядати у якості одного з основних елементів клінічного моніторингу.

Пропонується система моніторингу та управління факторами ризику хворих, що складається з двох кластерів - таких, що базуються на класичних дослідженнях в амбулаторних умовах та в рамках спеціалізованих установ. Особливістю подібної системи є застосування нових факторів ризику, так званих трендових, що відображають особливості динаміки показників та часу експозицій факторів ризику. Другою особливістю $\epsilon$ вивчення оперативних індивідуальних коефіцієнтів кореляції між простими та високоінформативними факторами ризику для отримання індикативних показників.

Підкреслимо, що оптимізація роботи лікаря в сучасних умовах щільно пов'язана з виявленням контингенту населення з факторами ризику виникнення захворювань на етапі первинної профілактики та виявлення захворювання при умові відсутності обізнаності пацієнта про наявність у нього патологічного процесу, запобігання розвитку ускладнень та побічної дії фармакологічних препаратів на етапі вторинної профілактики з метою подальшої диспансеризації таких пацієнтів та моніторингу їх стану.

Застосування МЕП може дозволити вирішення цієї задачі при застосуванні простих зрозумілих підходів.

Методи формального опису динаміки клінічних показників у завданнях класифікації.

У характеристиці стану пацієнта одним з найважливіших методів $€$ дослідження динаміки параметрів, тому що тільки в цьому випадку можна виявити істотні процеси, пов'язані з ії забрудненням. Однак, дотепер не розроблені коректні методики оцінки змін. У відомій мірі таке положення обумовлене більшою кількістю показників, що становлять сотні, навіть якщо враховувати тільки широко відомі й один етап дослідження.

Одним з можливих і методично найбільш пророблених шляхів рішення даної проблеми $є$ апроксимація ряду значень показника $x\left(x_{1}, x_{2}, \ldots, x_{n}\right)$ функцією $F(x)$ і подальша класифікація у безлічі $\{F(x)\}$, що представляє собою функціональні залежності зміни безлічі показників. При цьому виникає, однак, цілий ряд труднощів й, насамперед, у питанні про інтерпретації поняття «динаміка показника». Можна дати кілька шляхів формалізації динамічних змін деякого показника $(x)$ функціонального стану організму. Зупинимося на відносних його змінах. Подібний підхід до оцінки змін припускає вибір деякої точки, щодо якої виробляється вимір значень показника.

Нехай параметр стану пацієнта $x$ описується в часі деякою послідовністю точок $a_{1}, a_{2}, a_{3}, a_{4}, \ldots$ (рис. 2). Дані точки відповідають значенням розглянутого параметра на певних етапах $1,2,3,4, \ldots, n$ дослідження середовища. Виберемо деяку довільну точку $a^{\prime}$ (рис. 3), щодо якої будемо робити відлік значень. Потім введемо відносні величини:

$$
\frac{a_{1 x}}{a_{x}^{\prime}}, \frac{a_{2 x}}{a_{x}^{\prime}}, \frac{a_{3 x}}{a_{x}^{\prime}}, \ldots, \frac{a_{i x}}{a_{x}^{\prime}}, \ldots,
$$

де $a_{x}^{\prime}, a_{1 x}, a_{2 x}, a_{3 x}, a_{i x}-$ значення змінної $x$ у точках $a^{\prime}, a_{1}, a_{2}, a_{3}, a_{i}$ і позначимо їх через $\alpha_{1}, \alpha_{2}, \alpha_{3}, \ldots$, $\alpha_{\mathrm{n}} \ldots$

Визначимо події:

1. $m_{2} \leq d_{i} \leq m_{1}$

2. $d_{i} \leq m_{l}$

3. $d_{i} \leq m_{2}$ 


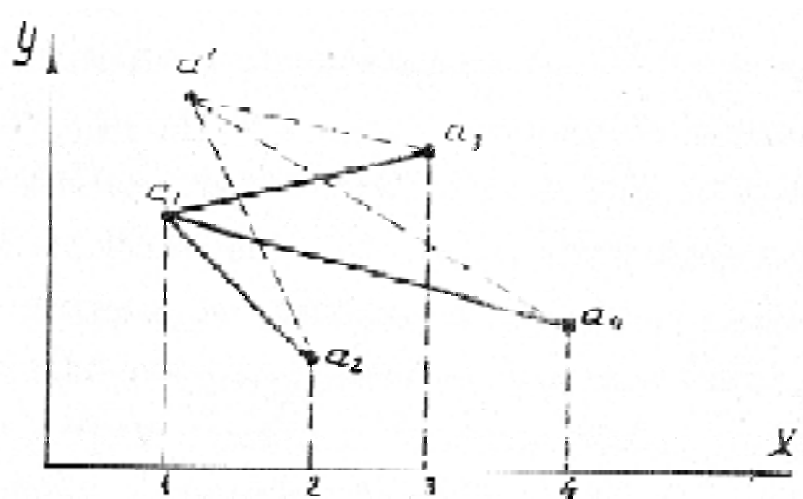

Puc. 2. Опис динаміки відносно першої точки.

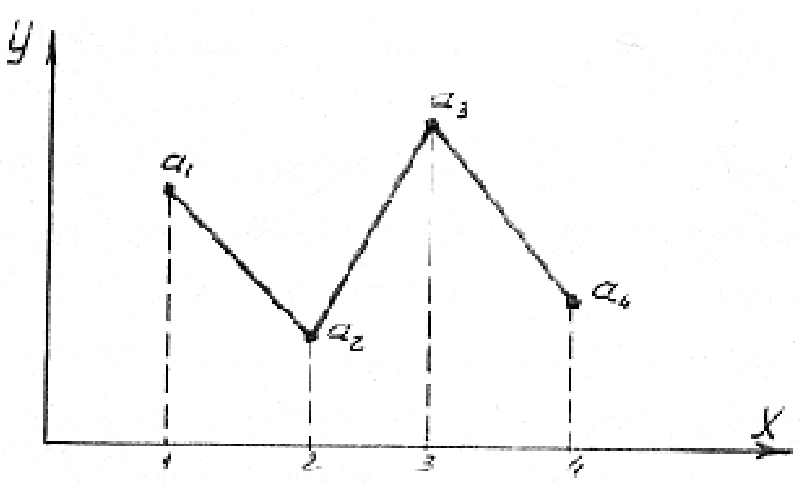

Puc. 3. Опис динаміки від етапу до етапу.

де $\mathrm{i}=1,2, \ldots, n ; m_{1}, m_{2}-$ верхні й нижні граничні значення. Введемо далі побуквене кодування певних подій алфавітом $B_{k}=\left\{\beta_{j}\right\}=\left\{\beta_{l}, \beta_{2}, \beta_{3}\right\}$, де $\beta_{l}, \beta_{2}, \beta_{3}$ позначає відповідно події $1,2,3$. Тоді зміни параметра $x$ на етапах дослідження можна виразити словом $\mathrm{B}$, що представляє собою відображення

$\left\{\alpha_{\mathrm{i}}\right\} \rightarrow\left\{\beta_{\mathrm{j}}\right\}$, де

$i=1,2, \ldots, n ;(n)$ - число етапів,

$j=1,2, \ldots, k ;(k)$ - кількість введених подій.

У розглянутому конкретному випадку уведено три події.

Наведений аналіз динаміки показника $x$ представляє загальний випадок. На практиці більш доцільно вибрати відлікову точку, рівну одному зі значень $x$, наприклад $a^{\prime}=a$, На рис. 2 загальний випадок представлений пунктирною лінією, а випадок рівності $a^{\prime}=a$ - суцільною. При $a^{\prime}=a_{1}$ динаміка $x$ буде розглядатися щодо вихідного значення $x$ (на першому етапі). При цьому перший етап $\epsilon$ дослідженням в умовах стаціонарного стану середовища, то такий випадок найбільш повно відповідає існуючим концепціям оцінки його стану.

Перейдемо тепер до іншого варіанта опису процесу динаміки показника $x$. За аналогією з розглянутим випадком введемо відповідні відношення:

$$
\alpha_{2}=\frac{a_{2}}{a_{1}}, \alpha_{3}=\frac{a_{3}}{a_{2}}, \alpha_{4}=\frac{a_{4}}{a_{3}}, \text { у загальному випадку } \alpha_{1}=\frac{a_{i}}{a_{i-1}} \text {. }
$$

Отже, на кожному етапі значення показника порівнюється з таким на попередньому етапі.

Розглянемо ще один випадок. Нехай параметр $x$ описується у часі значеннями $a_{x x}, a_{x 2}, a_{x 3}, \ldots, a_{x n} \ldots \mathrm{У}$ безлічі значень $\left\{a_{\mathrm{ix}}\right\}$ знайдемо $a_{\mathrm{xmin}}$ й $a_{\text {хmax }}$. Діапазон зміни параметрів $a_{\mathrm{xmin}}-a_{\text {xmax }}$ представимо у вигляді $m$ діапазонів. Далі визначимо можливі варіанти поводження параметра $x$ у такий спосіб:

$$
\begin{aligned}
& \text { 1. } \mathrm{a}_{\mathrm{x} \min } \leq \mathrm{a}_{\mathrm{xi}}<\mathrm{a}_{\mathrm{xmin}}+\frac{\mathrm{a}_{\mathrm{xmax}}-\mathrm{a}_{\mathrm{xmin}}}{m} \\
& \text { 2. } \mathrm{a}_{\mathrm{xmin}}+\frac{\mathrm{a}_{\mathrm{xmax}}-\mathrm{a}_{\mathrm{xmin}}}{m} \leq \mathrm{a}_{\mathrm{xi}}<2 \frac{\mathrm{a}_{\mathrm{xmax}}-\mathrm{a}_{\mathrm{xmin}}}{m}+\mathrm{a}_{\mathrm{xmin}} \\
& \text {.. } \\
& \text { m. } \mathrm{a}_{\mathrm{xmin}}+(\mathrm{m}-1) \frac{\mathrm{a}_{\mathrm{xmax}}-\mathrm{a}_{\mathrm{xmin}}}{m} \leq \mathrm{a}_{\mathrm{xi}} \leq \mathrm{a}_{\mathrm{xmax}}
\end{aligned}
$$

Код, що відповідає динаміці показника $x$ (В), буде визначений на множині: $\{1,2, \ldots, m\}$.

Було розглянуто три способи оцінки динаміки показника. Перший з них відображає поводження показника щодо довільної точки; більш повно відповідає практично цілям його модифікації, коли опис ведеться щодо вихідного значення показника, тобто значення на першому етапі пацієнта. Передбачається, що цим етапом $\epsilon$ експериментальні виміри в періоди стаціонарної й стабільної зміни параметрів. Другий спосіб оцінює динаміку від етапу до етапу, тобто на кожному наступному етапі обстеження проводиться порівняння з попереднім 
етапом. I, нарешті, останній спосіб припускає аналіз динаміки процесу щодо всього розмаху зміни параметра; назвемо його «масштабна сітка» (рис. 4).

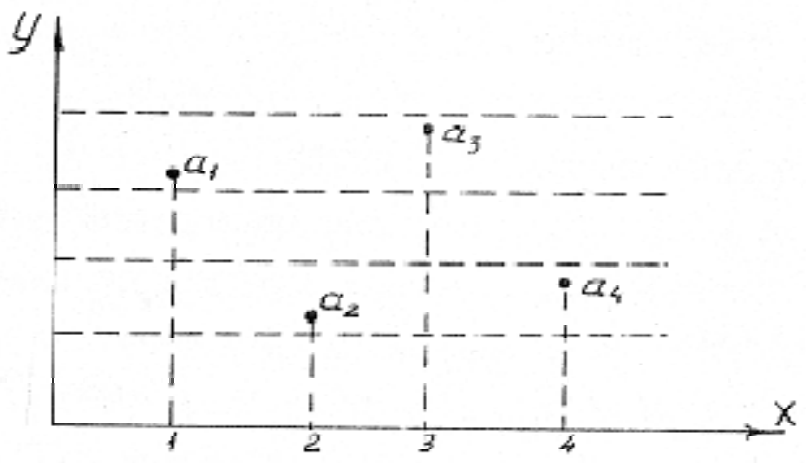

Puc. 4. Опис динаміки «маштабна сітка».

У підсумку вдається з різних сторін оцінити динаміку показників, що описують стан навколишнього середовища й з' ясувати, який із трьох способів у конкретному випадку дозволяє найбільш повно визначити природу розходжень їх поведінки.

Тобто, за допомогою простих систем кодування можна оцінити динаміку процесу, тобто охарактеризувати моніторинг стану пацієнта з урахуванням всього розмаху змін параметрів.

Пропонується використати схему кодування, згідно якої динаміка показників на визначених часових проміжках позначається цифрами 1 , якщо є різниця з еталонною кривою в бік зменшення значення фактора ризику, 0 - різниці немає або існує різниця в бік погіршення показника (наприклад, збільшення артеріального тиску). Отже, динаміка змін систолічного артеріального тиску у пацієнта А може бути виражена наступною послідовністю символів - 100001. Використовуючи даний спосіб кодування процесів, нам вдалося кількісно охарактеризувати динаміку показників стану кожного пацієнта.

Для підтвердження цієї гіпотези можливе використання поняття відстані за Хемінгом між двома послідовностями $d(X, Y)$, яке визначалося як число всіх компонентів послідовностей, які співпадають.

Невід'ємна функція $d_{I}(X, Y)$ називається відстанню або метрикою в деякій множині $E$, якщо для будь яких елементів $X, Y, Z$ з $E$ виконуються наступні умови:

$d_{1}(X, Y)=0$ тоді й тільки тоді, коли $\left.\left.X=Y ; 2\right) d_{1}(X, Y)=d_{I}(Y, X) ; 3\right) d_{1}(X, Y) \leq d_{1}(X, Z)+d_{I}(Y, Z)$.

В загальному вигляді відстань за Хемінгом задається в вигляді:

$d_{H}\left(X_{i}, X_{j}\right)=\sum_{s=1}^{p}\left|x_{i}^{(s)}-x_{j}^{(s)}\right|$

Так, відстань за Хемінгом між векторами 00111 і 10101 дорівнює 2 (рис. 5).

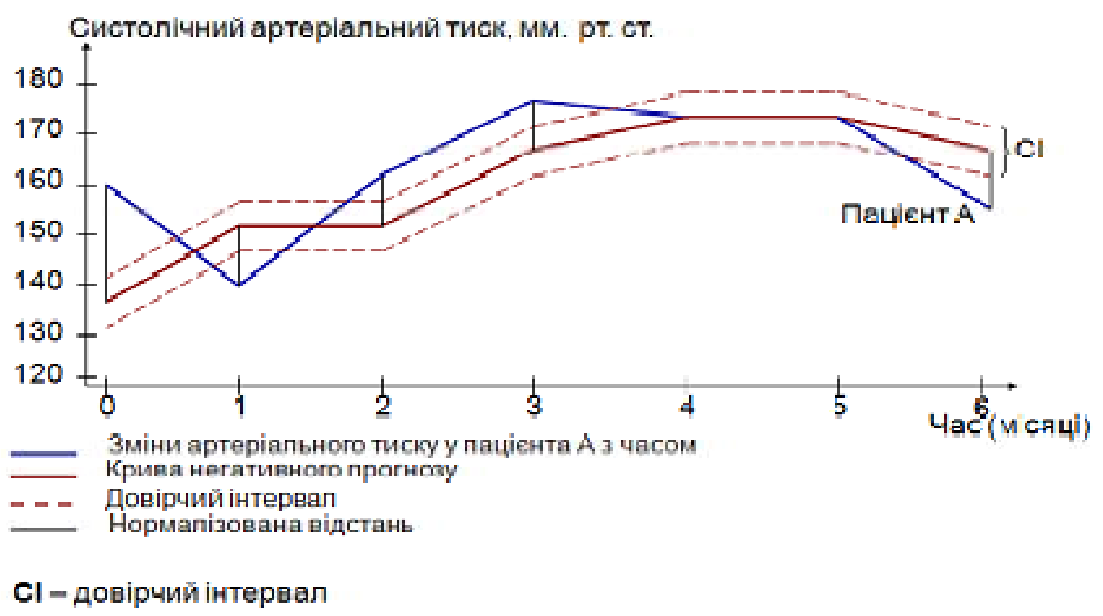

Puc. 5. Оцінка ризику (приклад). 
Ефективним $є$ використання методу кодування процесу від одного часового етапу до іншого. При його використанні легко вдається зіставляти довгі послідовності чисел, що відображають динаміку процесу.

Для прийняття рішень зазвичай обгрунтовуються відповідні пороги $\alpha$ та $\beta$, причому $\beta$ значно більше $\alpha$. Якщо порівняння здійснюється з еталонною кривою сприятливого результату, рішення щодо несприятливого результату приймається при значенні нормованої відстані більше більшого з порогів ( $\beta)$. Сприятливий результат прогнозується при значенні $d$ менше $\alpha$. Нарешті, якщо маємо нерівність $\alpha<d<\beta$, робимо висновок, що має місце невизначеність. Аналогічно здійснюється процес прийняття рішень при зіставленні $d$ зі значеннями еталонної кривої сприятливого результату розвитку хвороби, але розглядаються зворотні нерівності: висновок щодо несприятливого перебігу хвороби робиться при $d<$ альфа.

У прикладі, що розглядається нами, нормована відстань дорівнює $2 \backslash 6=0,33$. При порозі прийняття рішень, що дорівнює 0,4, можна зробити висновок, що ризик IXC великий. Отже, використання методу кодування процесу від одного часового етапу до іншого $є$ достатньо ефективним.

5. Формування вторинної структури щодо інформації про призначені лікарські засоби протягом життя людини.

В умовах впровадження медичного електронного паспорта громадянина України та суттєвого збільшення різноманітної фармацевтичної інформації (наприклад, інтенсивного розширення номенклатури лікарських засобів на фармацевтичному ринку України), потреба в об’ єктивних, структурованих і доступних даних, які б накопичувалися протягом життя людини, $є$ надто актуальною проблемою.

Слід також враховувати, що обсяг призначених пацієнтові ЛЗ з часом змінюється. Так, наприклад, наслідки від застосування у дитинстві ЛЗ, що змінюють флору кишечника (зокрема, антибіотиків) може проявитися через багато років. Тому інформація про ЛЗ, що міститься в МЕП, повинна бути класифікована та структурована в системі (наприклад, за допомогою логіки HTML).

Відомо, що до ЛЗ належать:

• діючі речовини (субстанції); готові ЛЗ (лікарські препарати, ліки, медикаменти);

- гомеопатичні засоби;

- засоби, що використовуються для виявлення збудників хвороб, а також боротьби із збудниками хвороб або паразитами; лікарські косметичні засоби та лікарські домішки до харчових продуктів;

- готові ЛЗ (лікарські препарати, ліки, медикаменти) - дозовані ЛЗ у тому вигляді та стані, в якому їх застосовують;

• діючі речовини (субстанції) - біологічно активні речовини, які можуть змінювати стан і функції організму або мають профілактичну, діагностичну чи лікувальну дію та використовуються для виробництва готових Л3;

• допоміжні речовини - додаткові речовини, необхідні для виготовлення готових ЛЗ;

• наркотичні лікарські засоби - лікарські засоби, віднесені до наркотичних;

• отруйні ЛЗ - ЛЗ, віднесені до отруйних Міністерством охорони здоров’я України;

- сильнодіючі ЛЗ - ЛЗ, віднесені до сильнодіючих Міністерством охорони здоров’я України;

• радіоактивні ЛЗ - ЛЗ, що застосовуються в медичній практиці завдяки їхній властивості до іонізуючого випромінювання.

Більш повна класифікація, що використана при конструюванні МЕП, наведена в додатках до НДР.

\section{6. Показники навколишнього середовища.}

Проблеми збереження і зміцнення здоров'я населення в сучасних умовах реформування соціально-економічних засад розвитку суспільства набувають особливої актуальності. Науково-технічний прогрес, швидкі темпи урбанізації супроводжуються зростанням техногенного навантаження на екологічну систему, збільшенням негативного впливу чинників довкілля на здоров'я населення. У зв'язку з цим проблеми забезпечення здорового довкілля та зменшення негативного впливу антропогенного забруднення на здоров'я людини стають одним з пріоритетних напрямів політики в охороні здоров'я. Саме на це націлює Європейська хартія 3 навколишнього середовища та охорони здоров'я (1989р.), Хельсинська декларація дій з охорони навколишнього середовища і здоров'я в Свропі (1994р.).

Загальні проблеми екологічних факторів довкілля, з одного боку, та стан здоров'я індивідуума чи популяції, з іншого, постійно привертають увагу дослідників світу. Але взаємозв' язок, що існує між здоров' ям населення і чинниками ризику, у т.ч. пов'язаними із проживанням в умовах забруднення довкілля, $\epsilon$ надзвичайно складним. Внаслідок цього досить різним $€$ сприйняття чинників ризику населенням і відповідно застосуван- 
ня профілактичних заходів. Підходи, що запропоновані в багатьох дослідженнях (WHO, 2002; WHO 2008; Pershagen G., 1999 тощо), в більшості характеризуються феноменологічним підходом. Більше того, як правило, в них рідко застосовуються характеристики здоров'я у взаємозв'язку з середовищем проживання. Лише в поодиноких роботах визначені кореляційні зв'язки між показниками, що вивчаються. До останніх можна віднести дослідження М.Г. Мельніченко (2005), де автор прослідковує зв'язок між забрудненням навколишнього середовища та захворюванням населення крупного промислового міста.

Сьогодні особливою проблемою $є$ науково обгрунтовані підходи до використання технологій превентивної медицини, що в світі є найгострішими. Особливе місце займають дослідження, що дають, з одного боку, параметри екологічної кон'юнктури, а з другого - параметри здоров'я населення. Причинно-наслідкові зв' язки в такому підході ще не вивчені в такій мірі, щоб дати можливість формувати профілактичні заходи.

В умовах зазначеного велике значення повинно надаватися системі моніторингу стану довкілля та управління ризиками (рис. 6).

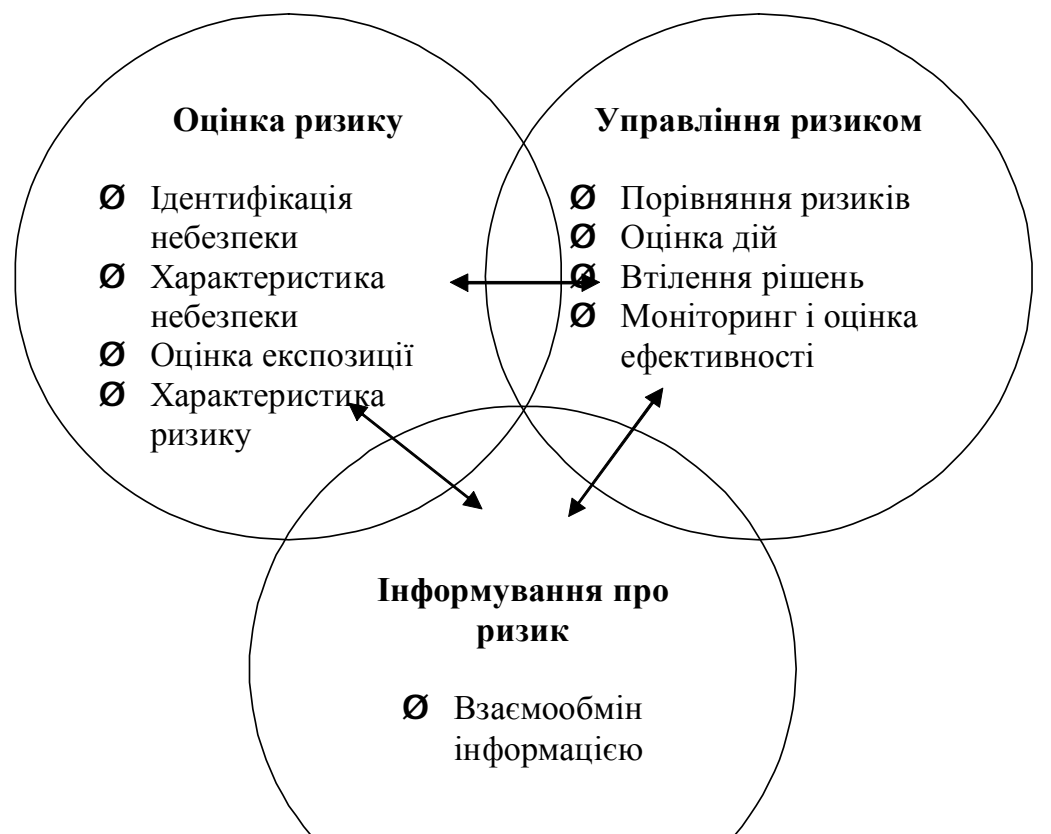

Puc. 6. Схема аналізу ризику для здоров'я.

Слід підкреслити, що МЕП надає всі можливості оцінити не тільки ризик для здоров'я людини, пов'язаний безпосередньо з екосистемою, але й ризик, пов'язаний з порушенням якості й умов життя.

Інформаційні аспекти оцінки ризику.

Для оцінки взаємозв'язку між впливом фактора ризику та частотою захворювань порівнювали значення обраного показника в досліджуваній і контрольній групах.

Використовували чотири види оцінки ефекту:

1. Відносний ризик (ВР), що показує у скільки разів захворюваність осіб, що перебувають під впливом, вища, ніж тих, що не перебувають під впливом, тобто кратність підвищення захворюваності в популяції (субпопуляції) при наявності даного фактора.

2. Додатковий (атрибутний) ризик або різниця ризиків (АР), що характеризує вибіркову захворюваність, пов' язану з розповсюдженістю факторів ризику.

3. Додатковий популяційний ризик, що характеризує захворюваність у популяції, пов' язану з поширеністю факторів ризику.

Додатковий ризик оцінюється як захворюваність для осіб, які піддавались впливу фактора ризику, за винятком захворюваності для осіб, які не піддавались цьому впливу. Він показує, зокрема, яка частка захворювань обумовлена впливом даного фактора. Якщо допустити, що вихідна захворюваність пов'язана з іншими причинами, то додатковий ризик - це додаткові випадки розвитку захворювання, обумовлені впливом фактора ризику. При такій ситуації фактор ризику повинен розглядатися як причина хвороби, а не як ії маркер. 
4. Додаткова частка популяційного ризику, що показує частку випадків захворювання в популяції, обумовлену впливом факторів ризику.

Додатковий ризик визначається, як захворюваність для осіб, що перебувають під впливом фактора ризику, за винятком захворюваності для осіб, що не перебувають під цим впливом. Він показує, зокрема, яка частка захворювань обумовлена впливом даного фактора. Якщо допустити, що вихідна захворюваність пов'язана 3 іншими причинами, то додатковий ризик - це додаткові випадки розвитку захворювання, обумовлені впливом фактора ризику. При такій ситуації фактор ризику повинен розглядатися як причина хвороби, а не як ії маркер. 3 огляду на спосіб обчислення додаткового ризику його також називають різницею ризиків.

Важливо представляти, що поняття відносного ризику, тобто відношення захворюваності серед осіб, які піддавалися й не піддавалися впливу факторів ризику, не несе інформації про величину абсолютного ризику (захворюваності). Навіть при високих значеннях відносного ризику абсолютний ризик може бути зовсім невеликим, якщо захворювання рідкісне. Відносний ризик показує силу зв' язку між впливом і захворюванням. Він служить мірою впливу факторів ризику, що важливо при вивченні етіології хвороби. Відносний ризик може змінюватися від 0 (у випадку, коли хвороба зустрічається тільки в одній групі) до нескінченності (якщо хвороба виникає тільки в групі, яка піддається впливу досліджуваного фактора) і дорівнює 1 за умови, що фактор взагалі не впливає на розвиток хвороби, тобто значення показників у досліджуваній і контрольній групах рівні.

Оскільки додатковий ризик відображає додаткову ймовірність захворювання, його застосування як індивідуального показника ризику в більшості клінічних ситуацій більш інформативне порівняно з відносним ризиком. 3 іншого боку, відносний ризик краще показує силу причинного зв'язку.

Одним зі способів перевірки гіпотези про істотність розходжень у ризику є розрахунок логарифмів довірчих інтервалів так званого коригованого відносного ризику з наступним переходом до нормальної шкали. Використання логарифмів ризику спрощує підрахунок стандартної помилки, необхідної для визначення довірчих інтервалів. При порівнянні трьох методів визначення нижньої границі довірчого інтервалу для відносного ризику при низьких рівнях захворювання й більших обсягів вибірок виявилося, що найбільшу точність при комп’ютерному моделюванні дає логарифмічне перетворення, що приводить розподіл оцінки $\mathrm{R}$ до нормального розподілу.

Приймалося доуваги, що якщо вплив фактора ризику сприяє розвитку хвороби, то відносний ризик перевищує 1.

Що стосується відношення ймовірностей розповсюдженості, що обчислюється аналогічно відношенню ймовірностей розповсюдження, то цей показник використали як оцінку співвідношення поширеності у випадку, якщо воно при даній хворобі низьке. У певних ситуаціях його й інтерпретували як коефіцієнт поширеності.

Застосовували також оцінку атрибутивного ризику на основі методу парних порівнянь. Дані заносили в таблицю й обчислювали оцінки відносного ризику та атрибутивного ризику, а також асимптотичні оцінки стандартних відхилень цих показників.

Для того, щоб визначити ризик у досліджуваному контингенті населення (або в популяції), що піддається впливу фактора ризику, обчислювали популяційний додатковий (атрибутивний) ризик як добуток додаткового ризику на розповсюдженість фактора ризику. Як відомо, цей показник відображає додаткову захворюваність, пов'язану з фактором ризику, тобто додаткову частку контингентного ризику. Останню розраховували шляхом розподілу додаткового популяційного ризику на загальну захворюваність у популяції.

Введемо поняття дуального моніторингу. Під ним будемо розуміти таке безперервне спостереження за станом здоров'я населення, при якому здійснюється дуальне управління за станом навколишнього середовища.

У свою чергу, під дуальним управлінням маємо на увазі класичне його визначення.

Дуальне управління (ДУ) - форма управління, при якій керуючі впливи служать одночасно для вивчення керованого об’ єкта і для приведення його до оптимального стану.

Як відомо, ДУ використовується в таких ситуаціях, коли точно невідомі закони поведінки досліджуваного об'єкта, а також немає достатньої початкової інформації, щоб заздалегідь розрахувати оптимальний закон управління. Саме такі випадки й мають місце при вивченні впливу забруднення навколишнього середовища на здоров'я населення.

У теоретичних дослідженнях, як правило, користуються терміном «система з неповною інформацією», для якої апріорно відомі не самі впливи, а лише статистичні характеристики випадкових вхідних впливів. Принцип дії цих систем полягає в тому, що вони накопичують відсутню інформацію вже під час роботи. Подібні системи одержали назву оптимальних систем з незалежним нагромадженням інформації через те, що процес 
нагромадження не залежить від алгоритму керуючого пристрою. У системі ДУ передбачається активне вивчення випадкових характеристик об' єкта управління, які змінюються.

Отже, на вхід об’ єкта подаються “вивчаючі” впливи, а реакція об’єкта аналізується керуючим пристроєм. У результаті, впливи, що управляють, використовуються не тільки для управління об’єктом, але одночасно і для його вивчення. При цьому основою для побудови алгоритму роботи керуючого пристрою $є$ теорія статистичних рішень, а показником якості - математичне очікування загальної функції втрат, що називають середнім ризиком.

Дуальне управління та моніторинг здійснювали на підставі визначення факторів ризику й обчислення додаткового (атрибутивного) ризику.

Вочевидь, обсяги вимірювань залежать від речовин та характеру діяльності підприємств. Уявлення про кількість щорічних вимірювань в місті Києві, а також поблизу підприємств дають рис. 7 і 8.

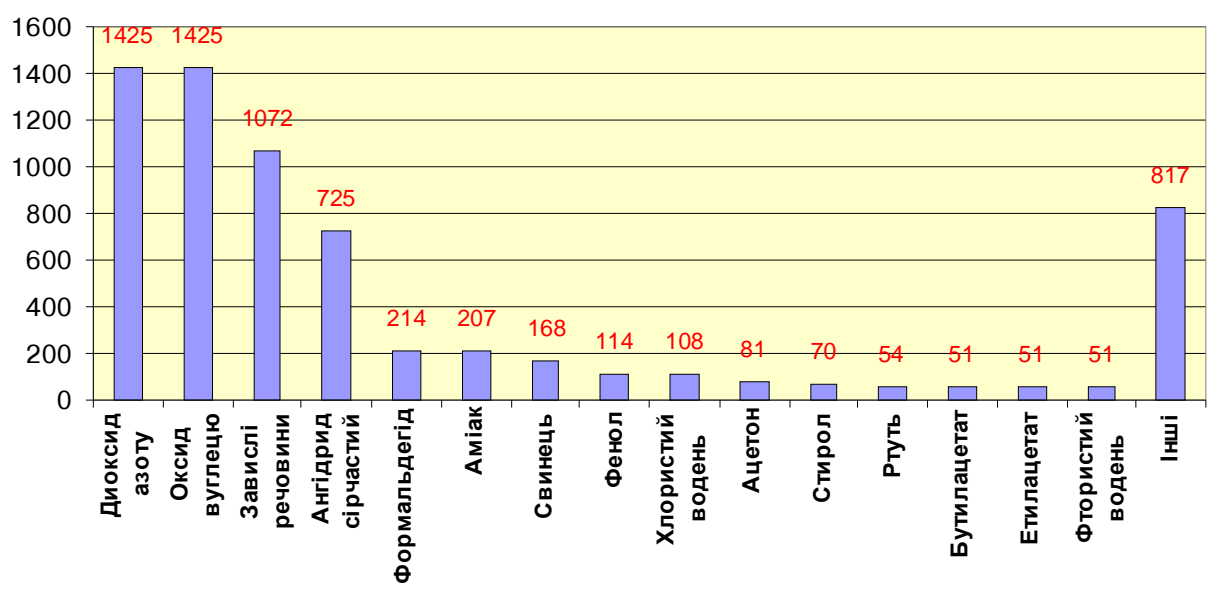

Puc. 7. Кількість вимірювань по забруднюючих речовинах у рік.

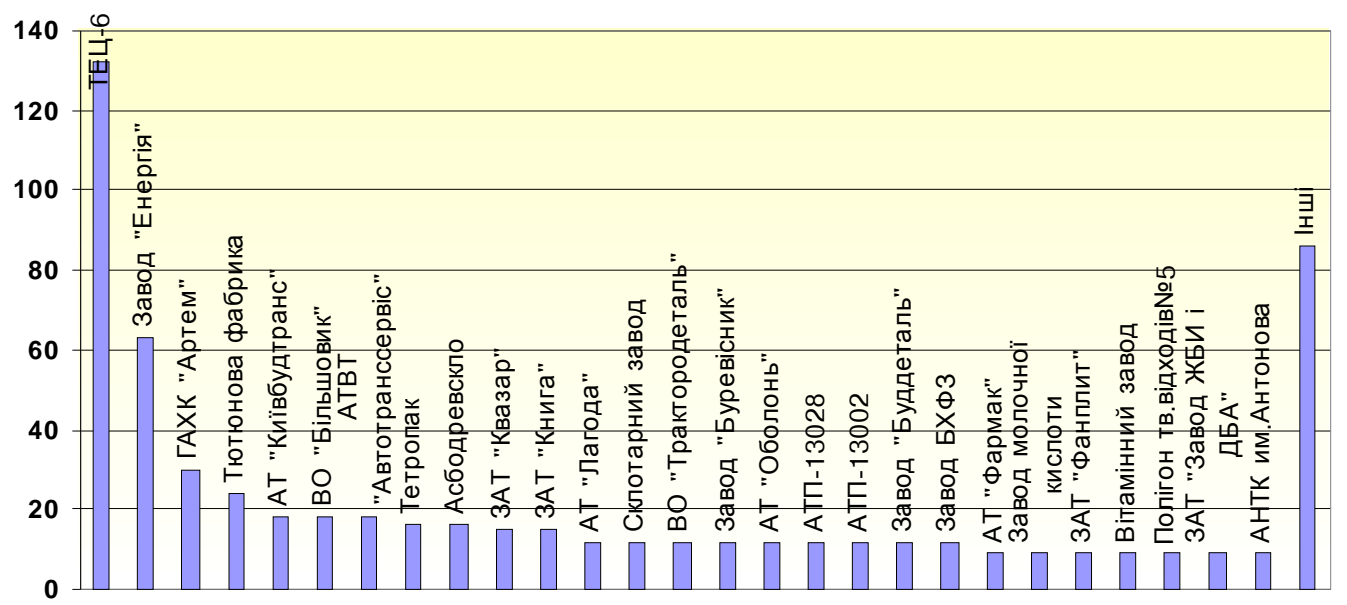

Puc. 8. Кількість вимірювань концентрації двоокису азоту в атмосферному повітрі поблизу підприємств у рік.

Контроль забруднення атмосферного повітря м. Києва забезпечувався 21-м постом спостереження. Забруднення атмосферного повітря Шевченківського району контролювалось стаціонарними постами спостереження забруднення (ПСЗ) № 7 та № 8 Центральної геофізичної обсерваторії Держкомгідромету України. Крім того, для контролю забруднення повітря використовувались дані експедиційних вимірів лабораторій районних та Київської міської санітарно-епідеміологічної станції (СЕС).

Проводився відповідний математичний аналіз матеріалів досліджень.

Спостереження за вмістом основних забруднюючих речовин (пил, двоокис сірки, окис вуглецю, двоокис азоту) проводились на всіх стаціонарних ПСЗ міста, а за вмістом специфічних (окис азоту, розчинні сульфати, сірководень, фенол, фтористий водень, хлористий водень, аміак, формальдегід, бенз(а)пірен, важкі метали: залізо, кадмій, марганець, мідь, нікель, свинець, хром та цинк) на окремих постах з урахуванням викидів промислових підприємств, розташованих поблизу ПСЗ і магістралей з інтенсивним рухом автотранспорту. 
Фактори ризику для здоров'я населення серед показників стану навколишнього середовища. Концептуальна основа.

Навколишнє середовище багатьох міських населених пунктів спотворене локалізованими районами економічної депривації та втрати стійкості, зокрема, тих, що деградували й прийшли в запустіння або периферійних зон, де екологічний збиток і соціальна ізоляція ідуть поруч. Це місця, що “функціонально деградували”, 3 поганими житловими умовами, недостатністю оснащення й устаткування систем життєзабезпечення, 3 незадовільними соціальними умовами. Були виявлені значні розходження в захворюваності й смертності між районами, що характеризуються невпорядкованістю і процвітаючими, заможними районами. Просторові ефекти та наслідки поляризації в деяких містах є настільки виразними, що з'явилися описи так званих “розділених міст”.

Як наслідок, населення міст підпадає під вплив цілого ряду факторів ризику, в основному, пов’ язаних із забрудненням навколишнього середовища. При цьому фактори ризику відображають та у значній мірі залежать від основних соціально-економічних умов. Будь-яка стратегія, спрямована на зміцнення здоров’я окремих людей, повинна враховувати ці фактори.

Концепція оцінки ризику практично у всіх країнах світу й міжнародних організаціях розглядається в якості головного механізму розробки й прийняття управлінських рішень як на міжнародному, державному або регіональному рівнях, так і на рівні окремого виробництва.

Підкреслимо, що здоров'я людини залежить не тільки від факторів ризику, пов' язаних з навколишнім середовищем. Сучасна методологія порівняльної оцінки ризику передбачає паралельний розгляд ризиків для здоров'я, екологічних ризиків, обумовлених порушенням екосистем і шкідливими впливами на водні і наземні організми (крім людини), ризиків зниження якості й погіршення умов життя.

Слід зауважити, що всебічна оцінка ризику впливу на здоров'я людини всіх потенційно шкідливих речовин хоча й бажана, але реально нездійсненна через великий обсяг дослідження й необхідних матеріальних ресурсів, а також через відсутність адекватних даних про рівні впливу й потенційної небезпеки ряду хімічних сполук. У зв' язку з цим, аналіз, зазвичай, проводиться на основі детального дослідження обмеженого числа пріоритетних (індикативних) речовин, які щонайкраще характеризують реальний ризик для здоров'я населення.

Взаємозв'язок, що існує між здоров'ям людини і навколишнім середовищем, є надзвичайно складним. Крім того, деякі фактори ризику виходять за рамки можливого їх контролю з боку окремої особи (наприклад, вдихання забрудненого атмосферного повітря на міській вулиці). Зрозуміло, що основні тенденції поширеності факторів ризику з боку навколишнього середовища та їх вплив на кількісні показники популяційного здоров' я ще недостатньо вивчені. Існують лише окремі статистичні дані, орієнтація на які повинна формуватися із застереженнями. Тому досить неоднозначним виявляється сприйняття фактора ризику населенням і відповідне вживання профілактичних заходів.

Зрозуміло, що при оцінці наявних хіміко-аналітичних даних, має здійснюватися адресна прив' язка постів спостереження та потенційних джерел забруднення з місцями проживання населення. Зазначене дозволяє наочно оцінити можливість екстраполяції даних, отриманих у конкретному місці відбору проб, на всю досліджувану територію. При цьому особлива увага приділяється місцям локального хімічного забруднення навколишнього середовища та правомірності використання отриманих хіміко-аналітичних даних у “гарячих точках" для характеристики рівнів експозиції на всій досліджуваній територіі.

В той же час, при проведенні оцінки ризику вихідне орієнтування на заздалегідь обмежене число індикативних речовин приводить до значних невизначеностей оцінки результатів і ускладнює вибір оптимальних способів управління ризиком.

Отже, необхідна система управління ризиками, що дозволяла б обгрунтовано виявляти пріоритетні проблеми, пов’ язані з навколишнім середовищем, ранжирувати ризики, джерела їхнього утворення, шляхи надходження хімічних речовин в організм, а також робити аналіз всіх невизначеностей для обгрунтування висновків і рекомендацій, необхідних для управління ризиком.

Використовували принципи дуального управління (ДУ), тобто таку форму управління, при якій керуючі впливи служать одночасно для вивчення керованого об'єкта і для приведення його до оптимального стану.

Як відомо, ДУ використовується в таких ситуаціях, коли точно невідомі закони поведінки досліджуваного об’єкта, а також немає достатньої початкової інформації, щоб заздалегідь розрахувати оптимальний закон управління. Саме такі випадки й мають місце при вивченні впливу забруднення навколишнього середовища на здоров' я населення. 
Підкреслимо, що у теоретичних дослідженнях, завичай, користуються терміном «система 3 неповною інформацією», для якої апріорно відомі не самі впливи, а лише статистичні характеристики випадкових вхідних впливів. Принцип дії цих систем полягає в тому, що вони накопичують відсутню інформацію вже під час роботи. Подібні системи одержали назву оптимальних систем з незалежним нагромадженням інформації. У системі ДУ передбачається активне вивчення характеристик об’ єкта управління, що змінюються.

На вхід об’єкта подаються “вивчаючі” впливи, а реакція об’ єкта аналізується керуючим пристроєм. У результаті, впливи, що управляють, використовуються не тільки для управління об' єктом, але одночасно і для його вивчення. При цьому основою для побудови алгоритму роботи керуючого пристрою $є$ теорія статистичних рішень, а показником якості - математичне очікування загальної функції втрат, що називають середнім ризиком.

В межах дослідження користувалися також логікою дуального моніторингу, тобто безперервного спостереження за станом здоров'я населення, при якому здійснювалося дуальне управління за станом навколишнього середовища.

Дуальне управління та моніторинг здійснювали на підставі визначення факторів ризику й обчислення додаткового (атрибутивного) ризику.

Підкреслимо, що дуальний моніторинг ризиків може виявитися ефективним способом вибору точок контролю, контрольованих хімічних речовин, установлення достатньої періодичності відбору проб тощо. Зрозуміло, що використовуватимуться не тільки виміри концентрацій численних хімічних речовин, що визначають ризики для здоров'я населення на даній території, але й прямі (безпосередньо пов' язані з оцінюваними ризиками для здоров'я) або непрямі індикатори якості середовища перебування людини. Останні досить добре відображають сукупне хімічне навантаження на населення.

Зауважимо, що подібна стратегія пов'язана з державним і регіональним регулюванням, впровадженням стандартів і захистом навколишнього середовища. При цьому норми регулювання й стандарти можугь використовуватися для перебудови й переорієнтації економічної діяльності на охорону навколишнього середовища й зміцнення здоров'я. Хоча регулювання й забезпечує рамки, в яких може відбуватися економічна діяльність, багато секторів виробництва вже усвідомлюють, що правильною практикою ведення справ $є$ забезпечення такого положення, при якому їхня економічна діяльність буде охороняти навколишнє середовище й зміцнювати здоров'я.

Регулюючі процедури варто широко використовувати для зменшення забруднення та утворення відходів.

Соціально-гігієнічний моніторинг як державна система спостереження, аналізу, оцінки й прогнозу стану здоров'я населення й середовища перебування людини, а також визначення причинно-наслідкових зв'язків між станом здоров'я населення й впливом факторів середовища перебування людини $\epsilon$, з одного боку, засобом управління ризиками (у тому числі, шляхом моніторингу експозицій і ризиків, динамічного спостереження за прямими і непрямими індикаторними показниками), а з другого, - системою, що надає відомості про реальні концентрації хімічних речовин в об'єктах середовища перебування людини, факторах експозиції.

Отже, методологію оцінки ризику можна розглядати в якості одного з основних, системоутворюючих елементів соціально-гігієнічного моніторингу. Важливу роль оцінка ризику відіграє в оптимізації відбору пріоритетних факторів для моніторингу, визначенні показників для контролю експозицій, обгрунтуванні вибору індикативних показників, засобів вимірювання, їх періодичності.

Моніторинг передбачає організацію на базі сучасних інформаційних технологій ієрархічного процесу збору, обробки, аналізу, збереження і видачі інформації для забезпечення динамічної оцінки стану навколишнього середовища та здоров'я населення, визначення прогнозу і прийняття обгрунтованих управлінських рішень, спрямованих на поліпшення довкілля та здоров'я.

Навколишнє середовище та здоров'я: ідентифікація небезпеки.

В останні роки набули поширення кількісні оцінки небезпеки, тобто здатності хімічного, фізичного, біологічного агента або сукупності певних факторів завдавати шкоди живому організму. Отже, небезпека є результатом фактичного або потенційного впливу хімічної сполуки та залежить від експозиції й специфіки конкретних умов впливу.

Ідентифікація небезпеки передбачає встановлення на якісному рівні вагомості доказів здатності того чи іншого агента викликати певні шкідливі ефекти у людини.

У науковому відношенні ідентифікація небезпеки представляє собою процес встановлення причинного зв' язку між впливом хімічної речовини й розвитком несприятливих ефектів для здоров'я людини, що передбачає 
поглиблений аналіз усіх наявних наукових даних про особливості поводження його в навколишньому середовищі й впливу на організм людини. Ідентифікація небезпеки $є$ не тільки початковим, але й ключовим етапом оцінки ризику, коли мають бути визначені граничні оцінки ризику.

Приймаючи до уваги виключну значимість стадії ідентифікації небезпеки, вважаємо доцільним проводити iї в три етапи.

На першому етапі проводиться оцінка існуючих (визначених) факторів ризику. Другий етап присвячується оцінці факторів ризику, що прогнозуються за даними моніторингу. Третій - основний етап полягає у зіставленні існуючих і прогнозованих факторів. Саме він дає можливість визначити валідність експериментальних даних. Головним при цьому слід вважати ідентифікацію закономірностей першого та другого етапів шляхом зіставлення аналізу факторів ризику і вихідних параметрів системи, що вивчається (в даному випадку показників здоров'я населення).

Основний принцип оптимальності розпізнавання ситуації, ідентифікації небезпеки й управління ризиками може бути сформульований так: термінове розпізнавання - прогнозування загрозливого стану (3С) і вибір такого управляючого впливу (УВ) з наявних ресурсів, що забезпечував би мінімальну ймовірність реалізації загрози. Під ЗС варто розуміти виникнення такого стану навколишнього середовища, що може становити реальну небезпеку здоров'ю людей.

Якщо обраний вплив буде недостатнім, то загрозливий стан буде прогресувати; якщо УВ буде надлишковий, то він стає економічно невигідним. Варто зазначити, що основний принцип оптимальності все-таки допускає проведення зайвих активних дій у всіх випадках, коли ризик небезпеки перевищує заздалегідь задану величину, що $€$ припустимою платою за зниження числа небезпечних помилок, пов'язаних з недооцінкою ситуації.

3 формальної точки зору система ідентифікації небезпеки $(\mathrm{CIH})$ вирішує наступні три завдання:

1) ідентифікація (діагностика) стану середовища в момент часу $t_{0}$ й у попередні моменти $t$, тобто визначення комплексу факторів $\left\{\tau\left(t \leq t_{0}\right)\right\}$;

2) прогноз реалізації погроз $\{h\}$ на тимчасовому інтервалі $\left[t_{0}, t_{0}+\Delta\right]$ при відомому комплексі факторів $\left\{\tau\left(t \leq t_{0}\right)\right\}$ і можливих на заданому тимчасовому інтервалі керуючих впливів $\{r\}_{l}, \ldots,\{r\}_{n}$;

3) вибір оптимального керуючого впливу плану дій, що мінімізують ймовірність реалізації загроз.

У припущенні про статистичну природу факторів ризику формула Байеса принципово дозволяє обчислити ймовірність реалізації загроз $P\left(\{h\} /\{\tau\},\{r\}_{i}\right)$ на інтервалі $\left[t_{0}, t_{0}+\Delta\right]$. Потрібно визначити такий план $\{r\}$, щоб імовірність реалізації загроз на даному інтервалі була мінімальною. Оптимальний план, а точніше кажучи “задовільний” план, шукається в класі управлінь, що складаються із двох частин - стратегії $\left\{r / R_{s}\right\}$ i тактики $\left\{r / R_{t}\right\}$. Наприклад, стратегія управління може складатися з припинення дії фактора (наприклад, закриття підприємств, що забруднюють навколишнє середовище), а тактика - у регламентації умов праці або життєдіяльності. Надалі під стратегією будемо розуміти вибір того чи іншого рівня допомоги - РД, відповідно, $R_{s}=$ $\left\{\mathrm{P}_{1}, \mathrm{P}_{2}, \ldots, \mathrm{P} Д_{\mathrm{k}}\right\}$.

По аналогії нами був запропонований спеціалізованний багаторівневий класифікатор УВ. У загальному випадку кількість рівнів й їхній зміст визначається характеристиками регіонів і ступенем забруднень, а також обраними доменами.

При багаторазовому рішенні однотипного завдання й достатній доказовій базі можуть бути розроблені Стандарти й протоколи дій санітарно-гігіснічної служби. При цьому будемо вважати, що відмінність протоколу від стандарту полягає в тому, що стандарт передбачає опис обов'язкового рівня допомоги, тоді як протокол містить положення рекомендаційного характеру.

На підставі стандартів і протоколів може бути розроблений детальний план дій за назвою «Стратегічний план дій (СПД)». Для клінічних завдань аналогічна проблема одержала назву «Критичного шляху».

Програма побудови СПД передбачає максимальний ступінь формалізації очікуваних результатів (OP) керуючих дій. ОР відіграють у плані роль «контрольних точок», які дозволяють здійснювати поточний моніторинг процесу. Прагнення до максимальної формалізації спричиняється можливістю ефективного використання інтелектуальних інформаційних систем.

Введемо поняття ефективного плану, що має місце тоді й тільки тоді, коли кожна його дія та заходи припустимі для конкретної ситуації; виконані всі необхідні заходи, немає надлишкових, чи таких, що приводять до незапланованих результатів, а також таких, які б скасовували результати попередніх дій. Стверджується, що ефективний план є формальною моделлю СПД. 
Під негативним процесом будемо розуміти стан динамічної загрози, яка зростає до реалізації при недостатньому управлінні та зменшується до прийнятного рівня (ліквідації) у протилежному випадку. Відповідно до даного визначення негативний процес у кожен момент часу $t$ визначається як сукупністю вже наявних ризиків $\{d(t)\}$, так і можливими загрозами $\{h(t)\}$ при обраному рівні управління $\{r(t)\}$.

Для числової характеристики стану середовища введемо поняття інтенсивності процесу погіршення стану середовища (ІППСС), що позначимо через $\gamma(t)$. ІППСС може являти собою ступінь загрози для здоров'я населення в найближчі $X$ годин з виявленими факторами ризику (наприклад, з ішемічною хворобою серця тощо). Схему обчислення ІППСС задамо в такий спосіб:

$V P V t\{\tau(t)\},\{d(t)\},\{r(t)\},\{h(t)\} \rightarrow 53 \rightarrow \gamma(t)$

Конкретне значення ІППСС вибирається $з$ деякого домена. ІППСС може вимірюватися в балах, відсотках, нечіткими лінгвістичними змінними тощо. Головною особливістю показника ІППСС є його інтегральний характер, що включає оцінку поточного стану й прогноз. 3 урахуванням доменів, можна записати:

VPVt Б3: $\{\tau / T\},\{d / D\},\{r / R\},\{h / H\}-\gamma(t) / \Gamma$

Приклад: “Оцінка ІППСС для зараженої місцевості”;

$\Gamma_{1},=[0 . .5]$ балів;

$\Gamma_{2}=\{$ Інтенсивність помірна (ускладнення малоймовірні); Інтенсивність висока (можливе виникнення хоча б одного із ускладнень) $\}$.

В якості відображення $\{\ldots\}>\gamma(t) / \Gamma_{l}$ може бути взята елементарна лінійна функція $F=\sum_{i=1}^{n} X_{i}$, де $X_{i}-$ бали ознак. При значенні $F$ не менше 3 покладається $\gamma(t) / \Gamma_{2}=$ «Інтенсивність висока», у протилежному випадку: $\gamma(t) / \Gamma_{2}=$ «Інтенсивність помірна».

В роботі запропоновано користуватися спеціальною шкалою ризиків. Якщо $P_{2}$ - імовірність більше небезпечного стану $A_{2}$, а $P_{1}$ - імовірність менш небезпечного стану $A_{l}$, то можна вважати, що загроза зростає при підвищенні ймовірності $P_{2}$ у порівнянні з імовірністю $P_{1}$, тобто при зростанні величини $P_{2} / P_{1}$ або ії логарифму $\lg \left(P_{2} / P_{1}\right)$. Весь спектр можливих значень логарифма становить шкалу ризику.

Інтенсивність зміни навколишнього середовища визначається за окремими факторами або в ціломуза їх сумою. До числа недоліків або, точніше, обмежень алгоритму подібного аналізу, належить те, що він $є$ бінарним (альтернативним) і при вирішенні багатоальтернативних завдань вимагає дихотомічного (поетапного) розгляду. Отже, він виходить із припущення про незалежність ознак й у звичайному варіанті не використовує інформацію про зв'язок ознак, тобто інформацію про симптомокомплекси. Можливі варіанти, які використовують цю інформацію, але вони застосовуються досить рідко через труднощі їхнього синтезу.

Розглянемо зміну показника ІППСС залежно від зміни рівня управління, що відповідає за стратегію. Нехай на тимчасовому відрізку $\left[t-\Delta_{i}, t\right]$ підприємство змінює рівень перебудови виробництва $P Д(t)$, а на відрізку $[t$, $\left.t+\Delta_{2}\right]$ рівень перебудови $Р Д\left(t^{+}\right)$. Таким чином, у момент часу $t$ відбувається стрибкоподібна зміна рівня перебудови. У рамках кожного фіксованого РД показник ІППСС яким-небудь чином змінюється зі зміною загального стану середовища. У момент часу $t$ показник ІППСС міняється також стрибкоподібно. Величина розриву визначається значеннями $\gamma\left(t^{+}\right) i \gamma\left(t^{+}\right)$.

Показник ІППСС має наступну важливу властивість: якщо $Р Д\left(t^{+}\right)>P Д(t)$, то $\gamma\left(t^{+}\right)<\gamma(t)$. Навпаки, якщо $P Д\left(t^{+}\right)<P Д(t)$, то $\gamma\left(t^{+}\right)>\gamma(t)$. На рис. 9 показана динаміка зміни показника ІППСС залежно від зміни рівня виконання підприємством санітарних приписів.

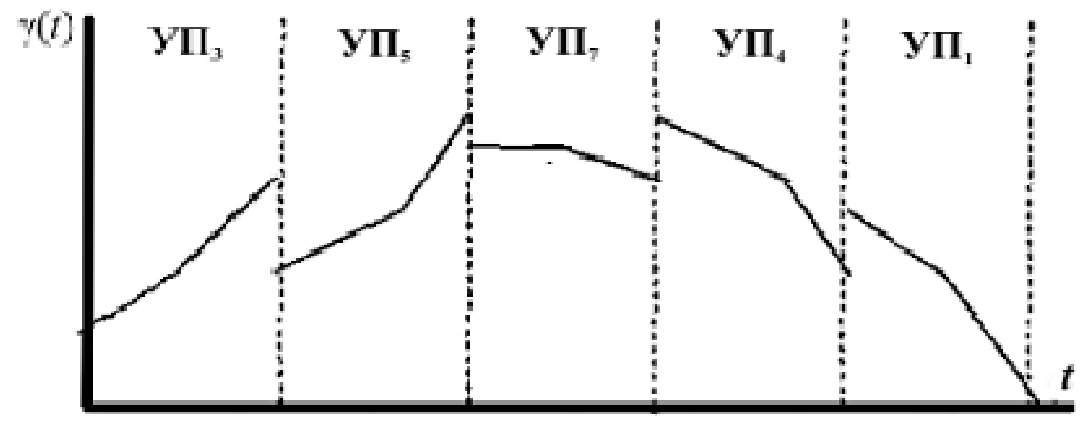

Puc. 9. Динаміка зміни показника ІППСС. 
Для кожного РД можуть існувати пороги $\gamma_{i}^{+}{ }_{i}{ }_{\text {й }}{ }_{i}$, які визначають доцільність переходу відповідно на більш високий РД (наприклад, РД ${ }_{i+1}$ ) чи більш низький РД (наприклад, РД ${ }_{i-1}$ ). Вибір порогів істотно залежить від принципу оптимальності діагностики й заходів, яким керується санітарна служба.

У забезпеченні безпечного навколишнього середовища беруть участь два суб’ єкти: санітарна служба й підприємства (очевидно, що лікар представляє інтереси санітарної служби). У кожного суб' єкта є свої багато в чому суперечливі інтереси й критерії ефективності, а також специфічні обмеження:

Критерії підприємства:

Час_Діагностики > min

Вага_Проблеми > min

Інакше кажучи, результатом роботи IC повинні бути кортежі, що містять набори тестів або заходів 3 відповідними оцінками за критеріями:

Час_Лікування > min

Обмеження підприємств (ситуативні):

Витрати_Підприємств $<$ C

Дискомфорт $=$ «Відсутній» $\mathrm{v}$ «Незначний»

Критерії санітарної служби:

Якість Діагностики > max

Вага_Проблеми > min

Витрати_Підприємств $>$ max

Ресурси_Підприємств > max

Обмеження суб'єктів забезпечення якості навколишнього середовища

Наявність ресурсів

Відхилення_Від_Стандартів $=$ «Відсутні» $\mathbf{v}$ «Незначні»

Вартість послуг погоджена з ринковими факторами.

Мінімізація ваги проблеми означає: відсутність несприятливих впливів при функціонуванні промислових підприємств, мінімальний обсяг викидів від автотранспорту тощо.

Ризик для здоров'я людини оцінювали з точки зору ймовірності розвитку захворювання або загрози здоров'ю майбутніх поколінь, що обумовлена впливом факторів середовища перебування.

Особливістю дослідження була спроба кількісно оцінити ефективність заходів щодо покращення навколишнього середовища шляхом вивчення динаміки потенщіальних показників небезпеки.

Аналіз динаміки забруднення атмосферного повітря центрального району м. Києва показав, що не дивлячись на спад виробництва в спостережувані роки та відсутність шкідливих промислових підприємств у центрі міста, має місце значне забруднення атмосферного повітря хімічними речовинами техногенного походження. Вміст багатьох шкідливих домішок атмосферного повітря значно перевищував гранично допустимі концентрації (ГДК), не мав тенденції до зниження, а навпаки, зростав. Все це створило несприятливу екологогігієнічну ситуацію й могло б обумовити появу негативних змін у здоров 'ї населення.

Аналіз результатів впровадження програми покращення стану навколишнього середовища в центральному районі та місті в цілому за останні 7 років (1998 - 2005 рр.) за 13 шкідливими речовинами показав, що середньорічні концентрації шкідливих речовин по 63 них мають стійку тенденцію до зниження в останні три роки.

Концентрації пилу зменшились у 2002-2005 рр. відповідно на 7-18\%, діоксиду сірки на 10-30\%, діоксиду азоту на 2-4\%, бенз(а)пірену на 10-40\%, хоча, починаючи з 2001 року концентрації бенз(а)пірену, діоксиду азоту та оксиду вуглецю зросли на $25 \%$ порівняно $з$ минулими роками.

Вміст хлористого водню зменшився у 1994 - 1998 рр. на 35-40\% , аміаку на 53-65\%, фенолу - на 31-52\% та формальдегіду - на 11-65\%, але, починаючи з 1999 року значення концентрацій хлористого водню, фенолу та формальдегіду почали помітно підвищуватись.

За іншими домішками суттєвих змін не спостерігалось.

Важливі висновки були зроблені щодо аналізу тенденцій факторів ризику. На рисунку показана динаміка окису вуглецю (СО) протягом останніх 7 років. Не спиняючись на хвильових добових коливаннях, звернемо увагу на місячні тенденції. Якщо середній рівень СО залишається майже стабільним і суттєво не перевищує значення ГДК, то пікові значення показника можуть значно її перевищувати. Не важко підрахувати, що коливання рівня забруднення окисом вуглецю відносно середньої кількості складає до 200-300\%. Подібне явище 
має місце для обох точок замірів. Зрозуміло, що визначення впливу в подібних випадках на основі середньомісячних характеристик дає великі помилки.

Вочевидь, можливо було б вивчати час експозиції. Але ж отримати валідну інформацію стосовно часу експозиції для конкретного мешканця практично неможливо.

Отже, негативні зміни стану навколишнього середовища є одними з найвагоміших факторів у погіршенні стану здоров'я населення. Факторіальне навантаження стану навколишнього середовища в аналізі впливу різних факторів на здоров’я населення досить суттєве і складає $0,55 \pm 0,04$. Подібне погіршення може також стати індикативним показником для ідентифікації небезпеки для здоров'я людини.

Широке застосування міжсекторальних підходів для вирішення медико-санітарних проблем населення можливо в більшій мірі зможе забезпечити поліпшення навколишнього середовища. Мають також впроваджуватися принципи системного підходу.

Ідентифікація небезпеки при оцінці стану навколишнього середовища має проводитися шляхом зіставлення наявних і прогнозних характеристик забруднення довкілля.

Важливим елементом комплексної оцінки небезпеки навколишнього середовища можуть бути дисперсійні характеристики параметрів його стану.

\section{7. Класифікація діагностичних моделей.}

Загальноприйнятий в сучасній медицині підхід характеризує у багатьох випадках лише одну сторону альтернативи “здоровий-хворий”. Вважається, що діагноз “здоровий” обгрунтований, якщо не виявлені ознаки маніфестації патологічного процесу, а всі показники функцій знаходяться в межах фізіологічної норми.

Навіть за наявності однієї альтернативи “здоровий-хворий” існує принаймні чотири стани: здоров”я - оптимальна стійкість до дії патогенних агентів, фізична, психічна і соціальна адаптивність до змінних умов життедіяльності; передхвороба - можливість розвитку патологічного процесу без зміни сили чинника (чинників), що діє, унаслідок зниження резервів здоров'я із ознаками саморозвитку процесу; стан, що характеризується наявністю патологічного процесу без ознак маніфестації; хвороба - патологічний процес, що маніфестує у вигляді клінічних проявів, відображається на соціальному статусі індивіда.

Зауважимо, що при формах опису існуючих хвороб дати характеристику здоров'я або виділити зазначені стани неможливо.

В наших дослідженнях були прийняті три типи моделей, що пов'язані з:

А. Нозологічною діагностикою.

Б. Донозологічною діагностикою.

В. Діагностикою здоров’я за прямими показниками.

Вибір моделі (діагностичний підхід) залежить від мети діагностики й визначає сукупність діагностичних прийомів (методик обстеження), на які спирається діагноз. Стан одного і того ж пацієнта може бути описаний різними діагностичними моделями. При цьому головними є не сукупність використовуваних ознак, а логіка їх інтерпретації й інтеграції при виробленні кінцевого діагностичного висновку. 3 цих позицій можна по-новому сформулювати поняття діагнозу: діагноз - логічна формула, що відображає стан індивіда, виражений в поняттях сучасної медичної науки.

Донозологічна діагностика. Охарактеризувати стадію адаптації можна трьома параметрами: рівнем функціонування системи, ступенем напруги регуляторних механізмів і функціональним резервом. Зазначені підходи і використані для характеристики донозологічних станів - стадій адаптаційного процесу. Стани адаптаційного потенціалу, що в той же час виділяються, хоча певною мірою і характеризують здоров'я, все ж таки це швидше результуюча взаємодії організму з навколишнім середовищем. Можна уявити собі індивіда 3 високим рівнем здоров'я, що потрапив в екстремальну виробничу або побутову ситуацію, котра призвела до зриву адаптації, не дивлячись на значні резерви функцій. 3 іншого боку, у хворого на стадії ремісії хронічного соматичного захворювання (наприклад, хронічної пневмонії) визначатиметься стадія задовільної адаптації, хоча рівень здоров'я у нього буде достатньо низьким.

Діагностика здоров'я за прямими показниками. До сьогодні найбільш поширені дві моделі діагностики рівня здоров'я за прямими показниками: визначення біологічного віку і оцінка енергопотенціалу на рівні організму. Обидві вони характеризують біологічну функцію виживання - один з основних проявів здоров'я. Без підтримки цієї функції решта проявів здоров’я неможлива. 
Проведені дослідження дозволили створити формалізовану систему оцінки рівня соматичного здоров'я (табл. 1, 2), що складається з ряду простих показників, які ранжовані, а кожному рангу привласнений бал, що відображає ступінь зв'язку даного показника з кінцевим результатом тесту. Загальна оцінка соматичного здоров'я визначається сумою балів.

Таблиця 1. Експрес-оцінка рівня соматичного здоров'я (чоловіки)

\begin{tabular}{|c|c|c|c|c|c|}
\hline \multirow[b]{2}{*}{ Показник } & \multicolumn{5}{|c|}{ Рівень здоров'я } \\
\hline & низький & $\begin{array}{c}\text { нижче } \\
\text { середнього }\end{array}$ & середній & $\begin{array}{c}\text { вище } \\
\text { середнього }\end{array}$ & високий \\
\hline \multicolumn{6}{|c|}{ Індекс маси тіла } \\
\hline$\frac{\text { маса тіла, кг }}{\left(\text { зріст, } \mu^{2}\right)}$ & $\begin{array}{c}18,9 \text { і менше } \\
(-2)\end{array}$ & $\begin{array}{l}19,0-20,0 \\
\quad(-1)\end{array}$ & $\begin{array}{l}20,1-25,0 \\
(0)\end{array}$ & $\begin{array}{l}25,1-28,0 \\
\quad(-1)\end{array}$ & $\begin{array}{c}28,1 \text { і більше } \\
(-2)\end{array}$ \\
\hline$\frac{\text { ЖСЛ }}{\text { маса тіла }}$, мл / кг & $\begin{array}{c}50 \\
(-1)\end{array}$ & $\begin{array}{l}51-55 \\
\quad(0)\end{array}$ & $\begin{array}{l}56-60 \\
(1)\end{array}$ & $\begin{array}{l}61-65 \\
(2)\end{array}$ & $\begin{array}{l}66 \\
(3)\end{array}$ \\
\hline \multicolumn{6}{|c|}{ Динамометрія } \\
\hline$\frac{\kappa и с т і}{\text { маса тіла }}, \%$ & $\begin{array}{l}\leq 60 \\
(-1)\end{array}$ & $\begin{array}{l}61-65 \\
(0)\end{array}$ & $\begin{array}{c}66-70 \\
(1)\end{array}$ & $\begin{array}{l}71-80 \\
(2)\end{array}$ & $\begin{array}{l}>80 \\
(3)\end{array}$ \\
\hline$\frac{Y C C \bullet A T_{c u c m}}{100}$ & $\begin{array}{l}\geq 111 \\
(-2)\end{array}$ & $\begin{array}{c}95-100 \\
(-1)\end{array}$ & $\begin{array}{l}85-94 \\
(0)\end{array}$ & $\begin{array}{l}70-84 \\
(3)\end{array}$ & $\begin{array}{l}\leq 69 \\
(5)\end{array}$ \\
\hline $\begin{array}{c}\text { Час, хв, } \\
\text { відновлення ЧСС } \\
\text { після } 20 \text { присідань } \\
\end{array}$ & $\begin{array}{l}\geq 3 \\
(-2)\end{array}$ & $\begin{array}{l}2-3 \\
(1)\end{array}$ & $\begin{array}{l}1,30-1,59 \\
\text { (3) }\end{array}$ & $\begin{array}{l}1,00-1,29 \\
(5)\end{array}$ & $\begin{array}{l}\leq 59 \\
(7)\end{array}$ \\
\hline $\begin{array}{c}\text { Загальна оцінка рівня } \\
\text { здоров’я, сума балів }\end{array}$ & $\leq 3$ & $4-6$ & $7-11$ & $12-15$ & $16-18$ \\
\hline
\end{tabular}

Таблиця 2. Експрес-оцінка рівня соматичного здоров’ я (жінки)

\begin{tabular}{|c|c|c|c|c|c|}
\hline \multirow[b]{2}{*}{ Показник } & \multicolumn{5}{|c|}{ Рівень здоров'я } \\
\hline & низький & $\begin{array}{c}\text { нижче } \\
\text { середнього }\end{array}$ & середній & $\begin{array}{c}\text { вище } \\
\text { середнього }\end{array}$ & високий \\
\hline \multicolumn{6}{|c|}{ Індекс маси тіла } \\
\hline$\frac{\text { маса тіла,кг }}{\left(\text { зріст, } \text { м }^{2}\right)}$ & $\begin{array}{c}16,9 \text { і менше } \\
(-2)\end{array}$ & $\begin{array}{l}17,0-18,6 \\
(-1)\end{array}$ & $\begin{array}{c}18,1-23,8 \\
(0)\end{array}$ & $\begin{array}{l}23,9-26,0 \\
(-1)\end{array}$ & $\begin{array}{c}26,1 \text { і більше } \\
(-2)\end{array}$ \\
\hline$\frac{\text { ЖСЛ }}{\text { маса тіла }}$, мл / кг & $\begin{array}{l}<40 \\
(-1)\end{array}$ & $\begin{array}{l}41-45 \\
(0)\end{array}$ & $\begin{array}{l}46-50 \\
(1)\end{array}$ & $\begin{array}{l}51-56 \\
(2)\end{array}$ & $\begin{array}{l}<56 \\
(3)\end{array}$ \\
\hline \multicolumn{6}{|c|}{ Динамометрія } \\
\hline$\frac{\kappa и с т і}{\text { маса тіла }}, \%$ & $\begin{array}{l}\leq 40 \\
(-1)\end{array}$ & $\begin{array}{l}41-50 \\
(0)\end{array}$ & $\begin{array}{l}51-55 \\
(1)\end{array}$ & $\begin{array}{l}56-60 \\
(2)\end{array}$ & $\begin{array}{l}\geq 61 \\
(3)\end{array}$ \\
\hline$\frac{Y C C \bullet A T_{c u c m}}{100}$ & $\begin{array}{l}\geq 111 \\
(-2)\end{array}$ & $\begin{array}{c}95-110 \\
(-1)\end{array}$ & $\begin{array}{c}85-94 \\
(0)\end{array}$ & $\begin{array}{l}70-84 \\
(3)\end{array}$ & $\begin{array}{l}\leq 69 \\
(5)\end{array}$ \\
\hline $\begin{array}{c}\text { Час, хв, } \\
\text { відновлення ЧСС } \\
\text { після } 20 \text { присідань } \\
\end{array}$ & $\begin{array}{l}>3 \\
(-2)\end{array}$ & $\begin{array}{l}2-3 \\
(1)\end{array}$ & $\begin{array}{c}1.30-1.59 \\
\text { (3) }\end{array}$ & $\begin{array}{l}1.00-1.29 \\
(5)\end{array}$ & $\begin{array}{l}\leq 59 \\
(7)\end{array}$ \\
\hline $\begin{array}{c}\text { Загальна оцінка рівня } \\
\text { здоров'я, сума балів }\end{array}$ & $\leq 3$ & $4-6$ & $7-11$ & $12-15$ & $16-18$ \\
\hline
\end{tabular}

Отже, оцінюється лише один з проявів здоров’я - біологічна функція виживання. Перевага представленої діагностичної системи - доступність для середнього медперсоналу, мала трудомісткість (10-12 хвилин на одного пацієнта), відсутність необхідності у складному устаткуванні - є підставою для їі використання при масових обстеженнях населення. 
Рівень соматичного здоров'я і старіння. За дани- Уэ | ми штаб-квартири ООН, кожного місяця мільйон жителів Землі переходить рубіж 60-річного віку, а понад 100 тисяч рубіж 80 років. Ці показники за останні роки неухильно зростали, і подібна тенденція збережеться i в майбутньому.

У зв'язку з цим багатьом країнам доведеться орієнтуватися в своїх планах розвитку на людей більш зрілого віку, бо процес старіння населення $є$ історичною зміною, яка вимагає змін в стилі життя окремої людини, сім'ї, країни, регіону.

Вважається, що розвиток, зростання і старіння організмів - процес наближення до кінцевого стаціонарного стану, що супроводжується зменшенням питомої швидкості теплопродукції (теорія Пригожіна - Віам). 3 етапу оогенезу відбувається безперервний процес "старіння" біосистеми - зниження швидкості теплопродукції. Швидкість “старіння" найбільша на ранніх стадіях роз-

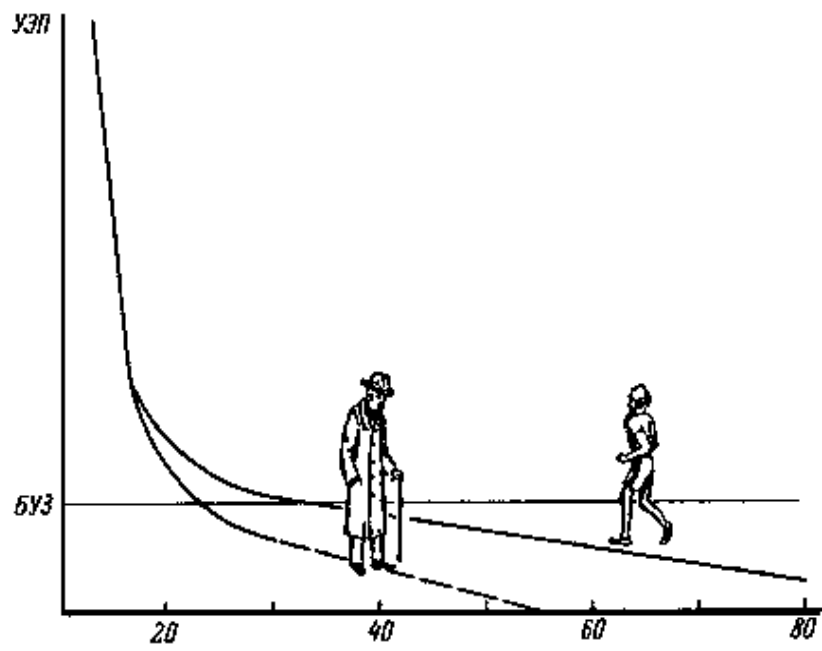

Puc. 10. Залежність тривалості життя (по горизонталі, років) від темпу зниження інтенсивності внутрішньоклітинного енергоутворення (по вертикалі).

витку, найменша - на кінцевих етапах онтогенезу. Досягнення кінцевого стаціонарного стану означає смерть. Починаючи з 25 років у людини зниження питомої швидкості теплопродукції складає 3,0-7,5 \% на кожних 10 років (рис. 10). В основі цього явища - зміна активності ферментів, концентрації мітохондрій у клітинах тощо. А це означає, що індивіди рухаються до свого стаціонарного стану з різною швидкістю, в різному віці переходячи межі “безпечного” рівня здоров'я.

\section{Методологічні принципи теорії індивідуального здоров'я.}

При загальному знайомстві з предметом своєї діяльності лікареві загрожує перспектива загубитися в масі інформації, деколи в дуже вузьких і специфічних напрямах цієї науки, і відчути їх відчуженість від пізнання цілісної людини. Фрагментарність накопиченої інформації- як наслідок захоплення аналітичними дослідженнями $-\epsilon$ тим принциповим недоліком, який можна подолати, використовуючи методологію теорії здоров'я для побудови з океану розрізнених фактів нового знання про медико-соціальну природу людини.

Абсолютно очевидно, що як показники, що кількісно характеризують рівень індивідуального здоров'я, можуть використовуватися тільки ті, що пов'язані з його сутнісними характеристиками. До них відносяться показники, що в тій або іншій мірі відображають діяльність механізмів самоорганізації живої системи - адаптації(Р.М. Баєвський, 1973; О.Г. Сорокин із співавт., 1996; М.П. Захарченко і ін., 2002, 2003 і ін.), гомеостазу (Ю.В. Мазурін із співавт., 1991; О.П. Мінцер, 1993 і ін.), реактивності (Л.Х. Гаркаві із співавт., 1990, 1996) тощо. Як показники рівня здоров'я переважно використовуються характеристики проявів здоров'я, оскільки вони відображають взаємодію багатьох механізмів самоорганізації живої системи - життєздатності (Г.Л. Апанасенко, 1985, 1992 і ін.), ефективності виконання соціальної функції (Г.Л. Апанасенко, 2000).

На жаль, пропонуючи нові методики діагностики здоров'я, деякі автори не указують на їх зв'язок з сутнісними його характеристиками або невірно трактують ці зв'язки. Ілюстрацією невірного трактування, що реалізовуються в практиці діагностики здоров'я, $є$ тест МКК (м'язово-кардіальної кореляції). Суть його полягає у визначенні коефіцієнтів лінійної кореляції між показниками деяких функцій. Чим вищі ці коефіцієнти, тим більше виражена, на думку авторів, інтеграція функцій, тим рівень здоров'я вищий. Насправді - все навпаки. Молодість і здоров'я, всупереч ортодоксальним уявленням, характеризуються нерегулярністю і непередбачуваністю ритму фізіологічних функцій. Чим вище коефіцієнти кореляції між показниками різних функцій, тим більше напруга в системі, тим менше “ступенів вибору” для неї за постійно змінних умов існування особини. Показано, наприклад, що погіршення умов виробництва, поява складних елементів у виробничому процесі приводять до зростання і зміцнення кореляційних зв' язків між показниками функцій працюючих. У спортсменів, за даними авторів тесту МКК, показники нижчі, ніж у молодих здорових людей, а випадків «відхилень» в стані здоров'я (вихід показників функцій за межі «норми») - більше. В той же час добре відомо, що резерви функцій спортсмена, його стійкість до екстремальних дій на порядок вищі, ніж у здорових людей, що не займаються спортом. 
До теперішнього часу найбільш поширені дві моделі діагностики рівня здоров'я за прямими показниками: визначення біологічного вікуі оцінка енергопотенціалу (резервів біоенергетики) на організмовому рівні. Обидві вони характеризують біологічну функцію виживання - один з основних проявів здоров'я. Без підтримки цієї функції решта проявів здоров'я неможлива.

\section{8. Створення архетипів для завдань охорони здоров'я.}

\section{Поняття архетипу. Необхідність застосування для завдань МЕП.}

Для розміщення інформації в медичному електронному паспорті остання повинна бути надана у вигляді формалізованої моделі багаторазового використання.

Відомо, що в перекладі з грецької архетип - це початкова модель, вперше сформований істинний тип. Стосовно області інформатики - формалізована і багаторазово використовувана модель деякого поняття предметної області. В медицині термін архетип був вперше введений і визначений у проекті openEHR: apxeтип - це оброблюване вираження, що містить у собі модель деякої частини предметної області у формі структурованих виражень-обмежень і засноване на еталонній інформаційній моделі системи. Архетипи openEHR засновані на еталонній моделі openEHR. Усі архетипи виражаються за допомогою того самого формального апарату. В цілому, вони призначені для повторного багатократного використання в широкому колі задач моделювання, проте можуть бути деталізовані і специфіковані для врахування особливості місця і ситуації, в якій вони застосовуються. Архетипи припускають можливість підтримки будь-якої кількості мов і термінологій.

Архетипи використовуються при створенні моделей представлення знань, де вони визначають припустимі структури даних.

openEHR - відкритий стандарт управління, збереження й обміну електронними історіями хвороби (ЕIX).

B openEHR усі дані про здоров'я людини:

- зберігаються протягом усього їі життя;

· формат даних не повинний залежати від організації, що цю інформацію розмістила;

- розміщена інформація орієнтована на людину.

Основною ціллю openEHR є обмін даними між EHR-системами; це основна ціль таких стандартів повідомлень, як ISO13606 і HL7.

Підтримує відкрите дослідження, розробку і реалізацію стандарту openEHR некомерційна організація openEHL7Foundation. Функціональні вимоги openEHR засновані на спільних 15-річних європейських і австралійських наукових дослідженнях в області EIX і нових парадигм, що включають у себе ідеї архетипів, котрі стали відомими завдяки документу archetype methodology.

Специфікація openEHR включає: інформаційну модель та інформаційні служби для електронної історії хвороби, для збереження даних про демографію (пацієнтів, персонал, який лікує), організації лікувального процесу, архетипів. Дані зберігаються з підтримкою версій. Вони є обгрунтованими медично й юридично, а також можуть бути правильно передані і зрозумілі в інший медичній інформаційній системі, заснованій на цьому ж стандарті.

Дворівневе моделювання з архетипами.

Ключовою інновацією в інтегрованому середовищі openEHR $€$ те, що всі деталі медичної інформації залишаються поза еталонною моделлю загальної інформаційної моделі системи, але, що найважливіше, надаються ефективні засоби вираження того, що лікарі і пацієнти вважають за необхідне заресструвати.

Медичні інформаційні моделі деталізовані формально, гарантуючи, що специфікації, відомі як «архетипи», піддаються обчисленню. Набір архетипів openEHR повинний бути перевірений на якість, щоб задовольняти декільком аксіомам, таким як взаємовиключення. Архетипи можуть управлятися незалежно від програмної реалізації й інфраструктури, руками лікарів-консультантів з метою гарантування, що вони відповідають реальним потребам лікарів. Архетипи розроблені таким чином, щоб дозволити параметрам медичних знань змінюватися і розвиватися згодом. Завдання впровадження проектного рішення подачі інформації, виражені в openEHR, сконцентровані до такого ступеня, щоб обмеження поточної системи залишалися узгодженими з проектним рішенням уявлення інформації.

В області ЕIX існує деяка кількість інформаційних моделей, котрими складно управляти в тих областях діяльності, де вони накладаються. Мова йде, наприклад, про моделі HL7 V3 i SNOMED CT. Модель openEHRє більш розвинутою моделлю, що буде вирішувати завдання гармонізації, якщо не буде використовуватися ізольовано. 
Звичайно, всі медичні записи будугь різними, але ключова інформація в інтегрованому середовищі ореnEHR завжди буде відповідати архетипам. Як це працює? Архетипи повинні виражати медичну інформацію таким чином, щоб вона могла використовуватися стільки разів, наскільки це можливо. Для того, щоб уявити інформацію, найбільш підходящу для лікувальної роботи, завжди варто використовувати деяку кількість архетипів. Ці набори називаються «шаблонами», множинами архетипів, що можуть бути уточнені для використання в конкретній ситуації. Шаблони можуть використовуватися, щоб деталізувати форми, документи і навіть повідомлення.

Підхід openEHR використовує «мову визначення архетипів», стандартизовану Європейською комісією зі стандартизації і Міжнародною організацією зі стандартизації (виражену у синтаксисі ADL або його XML еквіваленті) для створення архетипів; багаторазово використовуваних формальних моделей, побудованих на концепції доменів. Архетипи використовуються в openEHR, щоб змоделювати такі медичні дані, як «кров'яний тиск» або «медичний рецепт».

Міжнародне співробітництво.

Відповідно до підходу ореnEHR, використання загальнодоступних і регульованих архетипів дозволить гарантувати, що історії хвороби openEHR стануть узгоджено використовуваними і будуть переглядатися, незважаючи на їх технічний, організаційний і культурний контекст. Такий підхід також означає, що дійсні інформаційні моделі будь-яких ЕIX є гнучкими, виходячи з того, що можуть бути визначені нові архетипи для задоволення майбутніх потреб ведення медичних записів. Недавні роботи в Австралії показали, як архетипи і шаблони можуть бути застосовані для полегшення використання старих медичних карт, даних повідомлень у системі медичних записів ореnEHR, висновків стандартизованих повідомлень і складових документів.

Перспектива досягнення угоди щодо проектних рішень та форм регулювання на міжнародному рівні залишається спірною через різноманітні впливи, починаючи з розходжень у судово-медичному оточенні і до культурних відмінностей, технічних відмінностей, таких як, ступінь, до котрого відповідна медична термінологія може бути всеосяжною.

Інтегроване середовище openEHR узгоджується з новим Стандартом ведення електронних історій хвороби (EN 13606). Воно частково використовувалося в програмі Сполученого Королівства в області охорони здоров'я «UK NHS Connecting for Health Programme» і було обрано в якості основи для національної програми у Швеції. Воно також розвивається в ряді країн, таких як Данія, Словаччина, Чилі і Бразилія. Крім того, його починають використовувати в комерційних системах у всьому світі.

Визначення відкритого стандарту.

Стандарт називається відкритим, якщо він відповідає таким принципам:

1. Доступність. Відкритий стандарт доступний усім для читання і реалізації.

2. Максимізація вибору. Відкритий стандарт створює справедливий конкурентний ринок для реалізацій стандарту. Він не прив' язує споживача до визначеного постачальника або групи постачальників.

3. Відсутність ліцензійних відрахувань. Відкриті стандарти можуть бути вільно реалізовані всіма, без якихнебудь ліцензійних відрахувань або платежів. Проте сертифікація відповідності стандарту, вироблена організаціями, що стандартизують, може потребувати плати.

4. Відсутність дискримінації. Відкриті стандарти й організації, що їх адмініструють не повинні віддавати преваги одній реалізації перед іншими, з будь-яких причин, крім технічної відповідності реалізації стандарту. Організації, що сертифікують, повинні лишати можливість для підтвердження відповідності дешевих і безкоштовних реалізацій, але можуть також надавати додаткові послуги із сертифікації.

5. Розширення і підмноження. Реалізація Відкритого стандарту може бути розширена в порівнянні зі стандартом або пропонуватися у виді частини стандарту. Проте організації, що сертифікують, можуть відмовлятися сертифікувати часткові реалізації і можуть накладати обмеження на розширення.

6. Хижацькі практики. У відкритих стандартах можуть застосовуватися умови ліцензування, що захищають від підриву стандарту за допомогою тактики «Embrace-Extend-Extinguish». Пов'язана зі стандартом ліцензія може зажадати публікації довідкової інформації для розширень або привселюдної ліцензії на створення, поширення і продаж програм, сумісних із розширеннями. Не може бути ніяких інших заборон на розширення відкритого стандарту.

У визначенні OSI уточнюється, що відкритий стандарт не повинний залежати від технологій, що не відповідають вимогам відкритого стандарту. Визначення, зафіксовані в законодавстві Данії, Іспанії, Франції, Венесуели, в основному обмежуються вказівками на доступність самих стандартів і свободу їхньої реалізації. 
Відмінність відкритих $і$ закритих стандартів.

На відміну від відкритих стандартів, закриті стандарти мають локальну область придатності і підтримуються обмеженим системами та спеціалістами. Наприклад, служба каталогів Microsoft Active Directory (AD) грунтується на відкритому протоколі Kerberos, але Microsoft peалізувала Kerberos (protocol) таким чином, що цей засіб виявився несумісним із реалізаціями інших постачальників. Відкритий стандарт або формат даних аналогічний мові спілкування, однаково розуміється усіма в даній місцевості. Інтернет виник завдяки відкритим стандартам. Профінансувавши створення та реалізацію протоколу TCP/IP для Unix, агентство DARPA дозволило використовувати ці розробки всім бажаючим. Завдяки цьому оборонно державний проект виріс у світовий науковий і комерційний проект. 3 моменту свого створення Інтернет об'єднав тисячі (напевно правильно говорити - мільйони) індивідуальних комп'ютерів і мереж, розміщених у всьому світі.

Відкритий стандарт повинний задовольняти ще одній умові - бути затвердженим (сертифікованим) у якості міжнародного стандарту однією з міжнародних організацій зі стандартизації(ISO, IEEE, OASIS).

Третьою важливою ознакою варто назвати відсутність обмеження на використання стандарту / формату.

Деякі організації використовують для цього правило RAND (Reasonable and Non-Discriminatory).

Проте, i RAND негарантує свободи: воно дозволяє потребувати плату за кожну копію реалізації стандарту, а виходить, усі одержувачі повинні бути відомі автору.

Вигоди відкритих стандартів:

- Свобода дій. Документ у відкритому форматі можна складати з декількох джерел, переформатувати (у тому числі автоматично), а також видаляти компрометуючі метадані.

- Взаємодія в системах, складених із різнорідних компонентів. Інтернет складається з великої кількості устроїв різного призначення, що працюють під самими різними OC — Unix, Linux, Mac OS, Windows тощо.

· Низька ціна реалізацій. Досягається як широкою конкуренцією, так і нульовими витратами на ліцензування.

Недоліки відкритих стандартів:

· Слабкі механізми покарання за недотримання специфікацій. Якщо у випадку закритого стандарту можна загрожувати судом, для відкритого стандарту залишаються тільки державний захист (зокрема, ДОСТ) i відмова в сертифікації. Наприклад: на зорі війни браузерів компанії Netscape i Microsoft додавали в HTML візуальні теги.

- У деяких галузях діяльності зустрічається багато самоучок, які відступають від стандарту винятково через незнання. Наприклад: вебмастер прикріплює до HTML- документу.

· Відкриті стандарти з'являються, як правило, на вже сталому ринку. Бізнес, націлений на швидкий прибуток, першим з'являється з закритим форматом там, де цей прибуток очікується. Приклади: закриті формати WordPerfect i Microsoft Word, DVD-R i DVD-RW. Система електропостачання постійним струмом Едісона також була закритим форматом.

Розробка архетипів за матеріалами інструментальних досліджень.

Класифікація симптомів повинна сприяти контакту між клініцистом і дослідником та бути чимось більшим, ніж простим «найменуванням складових частин». Вона повинна відображати корисні кореляції з етіологією патологічного процесу, супутніх процесів, з вибором лікування і прогнозу. Зазвичай для цих цілей використовують одну класифікацію. Проте час від часу виникає необхідність використовувати додаткові класифікації для цілей, що мають абсолютно різні наслідки та вимагають різного лікування і прогнозу.

Відзначимо, що діагностична категорія симптому навряд чи буде корисна, якщо індивідууми з одним діагнозом значно не відрізнятимуться від індивідуумів з іншими діагнозами. Такі відмінності повинні тягнутися набагато далі за характеристики, що визначають діагностичну групу. Більш того, щонайменше деякі з ознак, на яких засновано розмежування різних діагнозів, повинні бути клінічно значущими.

Демографічні змінні, звичайно, слід враховувати, але ряд відмінностей між діагностичними групами повинні мати більш безпосереднє відношення до етіології, супутніх проблем, реакції на лікування або до прогнозу.

Можливо, що діагностичні категорії задовільні, а класифікація в цілому незадовільна. Таке буває, коли дуже велика кількість випадків не відповідає критеріям жодної категорії, а повинна бути підведена під терміни «атипова» або «змішана» категорія. Ідеальна класифікація настільки обгрунтована і всеосяжна, наскільки це можливо.

Класифікація, як правило, направлена на ознаки, що пред’являються до кожного розладу, а не на передбачувані етіологію або патогенез. Діагностичні категорії, засновані на патогенезі, як правило, перешкоджають 
прогресу в дослідженнях і в клініці, а не сприяють йому. I хоча велика частина розладів тепер визначається тільки на основі феноменології, деякі захворювання визначаються також і з погляду передбачуваної причини.

У ряді випадків аспекти інструментальної діагностики, мабуть, відображають крайні значення континууму, що продовжується в область норми, при цьому у багатьох пацієнтів ті ж самі ознаки виявляються у меншій мірі. В принципі, індивідууми з крайніми значеннями насправді є особливим випадком. Існує три можливі вказівки на розрив між нормальними і крайніми значеннями. По-перше, розподіл може бути бімодальним, наприклад, з додатковим максимумом в хвостовій частині основного розподілу. I, нарешті, індивідууми 3 крайніми і помірнішими значеннями за якою-небудь конкретною шкалою можуть якісно розрізнятися і в інших істотних відносинах.

У ряді випадків і розмірна, і категоріальна класифікація одних і тих же явищ бувають цінними, але для різних цілей.

Як приклад розглянемо динаміку холестерину в крові. Відомий взаємозв'язок між рівнем холестерину і ризиком ішемічної хвороби серця, при цьому найбільший ризик в популяції властивий великій кількості індивідуумів із значеннями «Високої норми», а не малій кількості з вкрай високими значеннями. В цьому відношенні високий рівень холестерину краще вважати розмірним, а не категоріальним розладом.

Слід розрізняти діагностичні схеми для стійких і ситуативних розладів. Стійкі розлади виявляються в широкому тимчасовому діапазоні, тоді як ситуативні розлади виявляються тільки в обмеженому діапазоні обстановок. Стійкість припускає, що основними є конституціональні особливості індивіда, тоді як ситуативна специфічність припускає, що більш важливо встановити, що особливого в цій конкретній обстановці (або в цьому конкретному інформанті).

Результатом нашого дослідження стало складання усередненої схеми архетипів рентгеноконтрастних та ультразвукових досліджень органів малого таза, що повністю представлені в додатках до НДР.

\section{Висновки.}

1. Для визначення параметрів, що відображають вплив навколишнього середовища на стан здоров'я людини, проведена серія експериментальних досліджень. Визначені тенденції показників індивідуального здоров'я понад 5000 чоловік одного з районів м. Києва за 10 років.

2. Обгрунтована принципово нова технологія визначення та кодування характеристик динаміки показників довкілля.

3. Визначено найбільш ефективне співвідношення коефіцієнтів асиметрії для характеристики динаміки факторів ризику навколишнього середовища.

4. Вперше запропонована технологія ідентифікації небезпеки навколишнього середовища для здоров'я індивіда.

5. Запропоновані й обгрунтовані статистичні моделі управління ризиками впливу стану навколишнього середовища на здоров'я населення.

6. Запропонована концепція дуального моніторингу стану здоров'я людини.

7. Для відображення результатів медичних дій при діагностиці та лікуванні захворювань, а також ефективності реабілітаційних заходів розроблена принципово нова класифікаційна схема показників якості надання медичної допомоги.

8. Розглянуті можливості внесення до МЕП (Національної медичної інформаційної системи) групи показників, що створюють генетичний паспорт людини. Відібрані 10 груп параметрів. Вони включають родовід; національність; каріотип; муковісцидоз, фенілкетонурію, гемофілію А, міодистрофію Дюшена, адреногенітальний синдром та інші моногенні хвороби, найбільш розповсюджені в даній популяції; дані про досимптомну діагностику генних хвороб з пізньою маніфестацією тощо.

9. Обгрунтована система “Внутрішнього моніторингу" станів пацієнтів у МЕП.

10. В якості основного механізму оптимізації тактики ведення пацієнтів запропонована система оцінювання ризиків. 


\section{ПЕРЕЛІК ПОСИЛАНЬ}

1. Апанасенко Г. Л. Здоровье спортсмена / Г. Л. Апанасенко // Наука в олимпийском спорте. - № 1. - 2000. - С. 34 - 40. 2. Апанасенко Г. Л. Физическое здоровье индивида: методологические аспекты / Г. Л. Апанасенко // Бюллетень Сибирского отделения АМНСССР. - 1988. - № 2. - С. 5-9.

3. Апанасенко Г. Л. Физическое здоровье и максимальная аэробная способность индивида / Г. Л. Апанасенко, Р. Г. Науменко // Теория и практика физической культуры. - 1998. - № 4. - С. 29 - 31.

4. Безматерных Л. Э. Диагностическая эффективность методов количественной оценки индивидуального здоровья / Л. Э. Безматерных, В. П. Куликов // Физиология человека. - № 3 (24). - 1998. - С. 79 - 85.

5. Булич Е. Г. Здоровье человека / Е. Г. Булич, И. В. Муравов - К. : Олимпийская литература, 2003. - 427 с.

6. Вернадский В. И. Философские мысли натуралиста / В. И. Вернадский - М. : Наука, 1988. - 172 с.

7. Голдбергер Э. Хаос и фракталы в физиологии человека / Голдбергер Э., Ригни Д., Уэст Б. // В мире науки. - 1990. - № 4. - C. $25-30$.

8. Чому вимирає українська людність / Голяченко О. М., Слабкий Г. О. [та ін.] // Новости медицины и фармации. - № 9. 2008. - C. $21-23$.

9. Горбатов В. С. Основы технологии РКІ / В. С. Горбатов, О. Ю. Полянская - М. : Горячая линия - Телеком, 2004. - 246 с. 10. Закон України “Про інформацію” № 2657-ХІІ від 02.10.1992.

11. Закон України “Про захист інформації в автоматизованих системах” № 80/94-ВР від 05.07.1994.

12. Крэг Ларман Применение UML 2.0 и шаблонов проектирования = Applying UML and Patterns : An Introduction to Object-Oriented Analysis and Design and Iterative Development. — 3-е изд. — М.: Вильямс, 2006. — С. 736.

13. Матеріали виїзного спільного засідання Комітету і Верховної Ради України з питань науки і освіти та Консультативної ради з питань інформатизації при Верховній Раді України. - К. : Софтпрес. - 208 с.

14. Мінцер О. П. Обеспечение валидности процедур использования медицинского электронного паспорта в здравоохранении. - Авторське свідоцтво ПА №4539 від 26.07.01.

15. Мінцер О. П. Статистика будущего - путь через персонифицированные базы данных / Мінцер О. П., Гойда Н. Г., Бабінцева Л. Ю. // Матеріали конференції „Демографічна та медична статистика України у ХХІ столітті. Медичні інформаційні системи у статистиці", 4 - 5 листопада 2004 р., м. Київ. -С. 29-31.

16. Основы стандартизации в здравоохранении; под ред. чл-корр. РАМН Вялкова А.И. и проф. Воробьева П.А. - М. : НЬЮДИАМЕД, 2002.-216 с.

17. Управление ЛПУ в современных условиях 2009-2010гг. ; под ред. акад. РАМН В.И. Стародубова. - М.: Менеджер здравоохранения, 2010.-210с.

18. Beale T. A Model Universe for Health Information Standards (2003). - Режим доступу: http://www.deepthought.com.au.

19. Blobel B., Hasman A. Harmonising advanced architectural approaches for distributed Electronic Healthcare Records towards a model driven EHR architecture, Int. J. Med. Inf., submitted for publication.

20. International Journal of Medical Informatics, Volume 77, Issue 5, May 2008, Pages 291-304 K. Hayrinen, K. Saranto and P. Nykanen: Режим доступу: http://www.sciencedirect.com/science? ob=ArticleURL\& udi=B6T7S-4PYJCRV1\& user=4346073\& coverDate $=05 \% 2$ F3 1\%2F2008\&_alid $=769026767 \&$ rdoc $=4 \&$ \&orig $=$ search \&_cdi $=5066 \&$ \&ort $=$ d $\&$ _docanchor $=\&$ view $=$ c \&_ct $=20 \&$ _acct $=$ C $000062970 \&$ _version $=1 \&$ _urlVersion $=0 \&$ \& userid= 4346073\&_fmt=full\&md5=be395dd6a8f357f1941319d1fb7fc6cd\#bib21bib21

21. Health Information Systems Advisor: Режим доступу: http://www.informaticsnurse.com/forums/informatics-job-descriptiondatabase/13716-clinical-ehr-health-information-systems-advisor.html

22. ISO/HL. ISO/HL7 27931:2009 Data Exchange Standards - Health Level Seven Version 2.5 — An application protocol for electronic data exchange in healthcare environments. OSI. Эталонная семиуровневая модель OSI (Open System Interconnect). - http://www.pbxlib.com.ua/network/article_164.html.

23. Final draft of CEN Report: Health informatics- Electronic healthcare record communication - Domain model. CEN/TC 251/ NOO-048, 2000-07-18. - Режим доступу: http://www.centc25l.org.

24. Режим доступу: http://integration.ibs.ru/content/rus/203/2038-article.asp.

25. Режим доступу: http://www.bacula.org/en/

26. Wikipedia. Режим доступу: http://en.wikipedia.org/wiki/. 